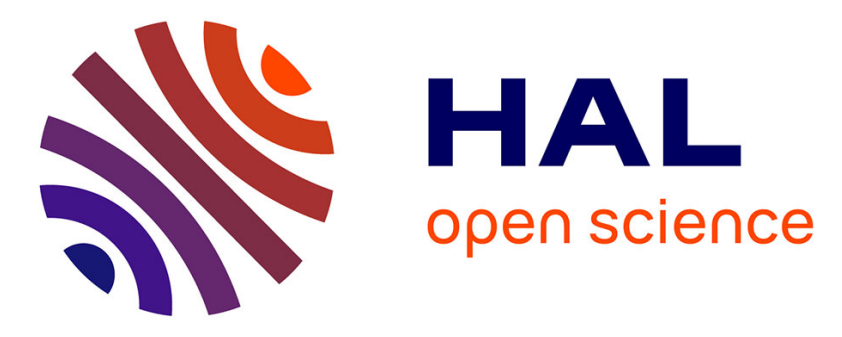

\title{
Cooling and stirring failure for semi-batch reactor: Application to exothermic reactions in multiphase reactor
}

Helisoa Rakotondramaro, Johan Wärnå, Lionel Estel, Tapio Salmi, Sébastien Leveneur

\section{To cite this version:}

Helisoa Rakotondramaro, Johan Wärnå, Lionel Estel, Tapio Salmi, Sébastien Leveneur. Cooling and stirring failure for semi-batch reactor: Application to exothermic reactions in multiphase reactor. Journal of Loss Prevention in the Process Industries, 2016, 43, pp.147-157. 10.1016/j.jlp.2016.05.011 . hal-02435638

\section{HAL Id: hal-02435638}

https://hal-normandie-univ.archives-ouvertes.fr/hal-02435638

Submitted on 25 Jan 2022

HAL is a multi-disciplinary open access archive for the deposit and dissemination of scientific research documents, whether they are published or not. The documents may come from teaching and research institutions in France or abroad, or from public or private research centers.
L'archive ouverte pluridisciplinaire HAL, est destinée au dépôt et à la diffusion de documents scientifiques de niveau recherche, publiés ou non, émanant des établissements d'enseignement et de recherche français ou étrangers, des laboratoires publics ou privés. 
Cooling and stirring failure for semi-batch reactor: application to exothermic reactions in multiphase reactor

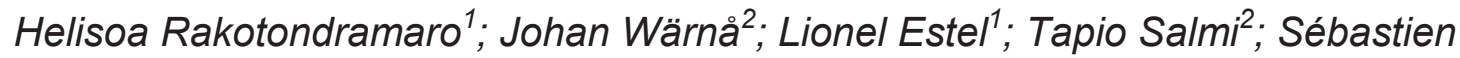
Leveneur ${ }^{1,2}$

1. Laboratoire de Sécurité des Procédés Chimiques (LSPC), EA4704, INSA Rouen ,685 Avenue de l'université, BP 08, 76801 Saint-Etienne-du-Rouvray, France. Tel: +33 2329566 54; Fax: +33 2329566 52; E-mail: sebastien.leveneur@insa-rouen.fr

2. Laboratory of Industrial Chemistry and Reaction Engineering, Johan Gadolin Process Chemistry Centre, Åbo Akademi University, Biskopsgatan 8, Fl-20500 Åbo/Turku, Finland. 


\begin{abstract}
Thermal safety assessment for multiple exothermic reaction systems in multiphase reactors is challenging. One of the first step is to determine the presence or absence of secondary reactions producing non-condensable gaseous products. Then, a kinetic and thermal study should be performed to evaluate the value of the heat-flow rates due to chemical reactions. Epoxidation of a free fatty acid by a percarboxylic acid produced in-situ was studied. A classical approach by determining the adiabatic temperature rise $\left(\Delta \mathrm{T}_{\mathrm{ad}}\right)$ and the time to maximum rate under adiabatic conditions (TMR $\left.\mathrm{Td}_{\mathrm{ad}}\right)$ by microcalorimetry was used. Then, different cooling and stirring failure scenarii in a semi-batch labscale reactor under isoperibolic mode were performed. It was confirmed that the formation of peroxyformic acid governs the overall reaction kinetics and the reaction temperature. It was confirmed that in case of cooling failure, mechanical agitation should be maintained.
\end{abstract}

Keywords: liquid-liquid reactions, cooling failure, accelerating rate calorimeter, thermal risk assessment, stirring failure, epoxidation. 


\section{Introduction}

Since the first oil crisis in the 1970's, academic, political and industrial communities have decided to focus their efforts to diminish the energy consumption. Furthermore, environmental concerns have pushed these communities to minimize the amount of industrial waste. Biomass valorization into chemicals and fuel components can contribute to overcome this challenge through the philosophy of green chemistry (Paul Anastas and John Warner, 1998). The advantage of using biomass as raw material is to diminish the dependency on the crude oil resources, using renewable materials and biodegradable ones.

Biomass valorization includes several steps of pretreatment, transformation and separation. To determine whether a biomass process is less energy demanding than its oil-based concurrent, intrinsic kinetic parameters and thermodynamic constants should be determined. The book of Debalina Sengupta and Ralph W. Pike (2013) giving different biomass valorization process simulation shows the complexity of this research activity.

Two major questions remain:

- Biomass valorization processes are greener but are they safer?

- How to make a thermal safety assessment in presence of consecutive reactions in multiphase reactor?

These are the crucial issues to be considered. 
Thermal risk assessment of chemical processes could be difficult to carry out because the knowledge of reaction kinetics and thermodynamics are required. Due to the high industrial competition and the time consumed in the estimation of kinetic and thermodynamic parameters, safety criteria are usually determined based on rapid microcalorimetric and calorimetric analysis.

In case that kinetic data are not accurately determined, some authors have developed the concept of boundary diagram for semi-batch reactors for liquidliquid reaction systems (Steensma and Westerterp, 1988; Steensma and Westerterp, 1990; van Woezik and Westerterp, 2001; Maestri and Rota 2006) by defining some dimensionless quantities.

The other issue for a liquid-phase reaction system is the presence of secondary reactions producing non-condensable gaseous products. These reactions can take place during the loss of the heat control. To evaluate the importance of these secondary reactions, different adiabatic reactors have been developed to follow as well the evolution of gas pressure such as Accelerating Reactor Calorimeter (ARC), Advanced Reactive System Screening Tool (ARSST) and Vent Sizing Package (VSP).

Valorization of vegetable oils to chemicals or to biofuels illustrates that thermal risk assessment can be problematic. Based on a report from IEA Bioenergy by Frank Rosillo-Calle, et al. (2009), the worldwide production of vegetable oils has increased since 1975. The predominant use of vegetable oils is for alimentary products but there is an increase of industrial and biodiesel applications. As 
illustrated by Fig. 1 (Nohra et al., 2013), different ways of vegetable oil valorization exist.

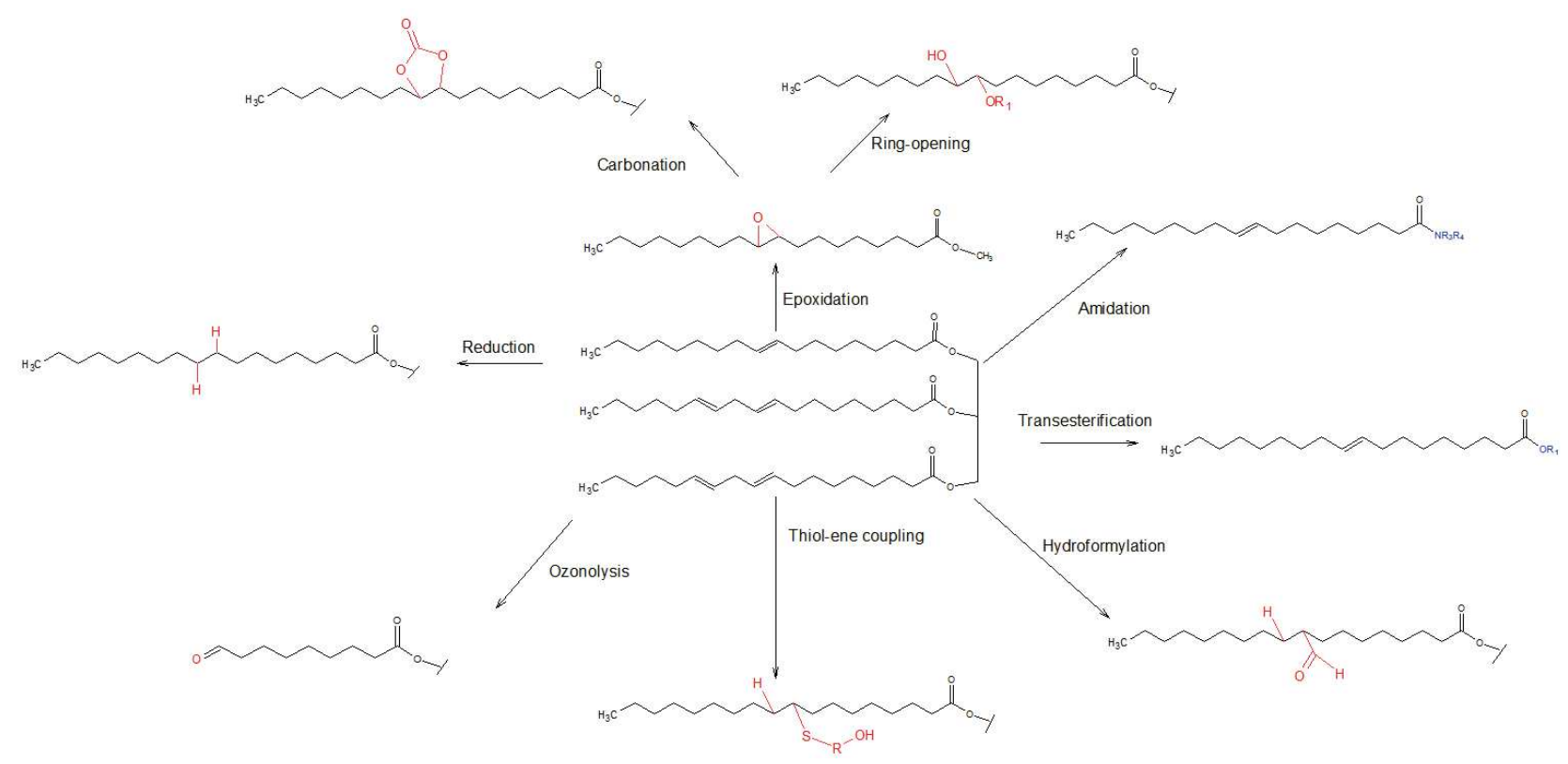

Fig. 1 - Different ways of vegetable oil valorization (Nohra et al., 2013).

Except for the production of biodiesel, which is industrially performed in continuous reactors such as Esterfip-H process (Boucot et al., 2003), the other processes of vegetable oil valorization are performed mostly in batch or semibatch process. The application of batch processes is due to small annual production volumes. From the safety viewpoint, the risk of thermal runaway is higher by using semi-batch and batch reactor.

Vegetable oils epoxidation by Prileschajew oxidation illustrates the complexity of the thermal risk assessment due to the presence of several consecutive exothermic reactions. It is an exothermic liquid-liquid reaction system. Different kinetic models (pseudo-homogeneous or two-phase model) have been proposed 
to describe this system (Sinadinović-Fišer et al., 2012; Santacesaria et al., 2012; Leveneur et al., 2014a; Zheng et al., 2016). Some authors have highlighted that the control of the temperature process is essential for this reaction (Monono et al., 2015; de Quadros Jr. et al., 2016). The production of percarboxylic acid by the corresponding carboxylic acid and hydrogen peroxide represent a risk of thermal runaway ( Leveneur et al., 2012; Ni et al., 2016).

Oleic acid epoxidation by peroxyformic acid (PFA) produced in situ has been studied (Leveneur et al., 2014b) from a thermal safety aspect. Oleic acid was selected as a model molecule because it is a common fatty acid in vegetable oils. Peroxyformic acid is prepared in situ from hydrogen peroxide and formic acid in the aqueous phase (Fig. 2). Then, peroxyformic acid undergoes spontaneous decomposition (Leveneur et al., 2014a; Leveneur et al., 2012) or transfers to the organic phase to epoxidize the unsaturated group. Ring-opening by water, formic and peroxyformic acid proceed in the organic phase. This process is exothermic and the production of PFA governs the exothermicity of the reaction system. 


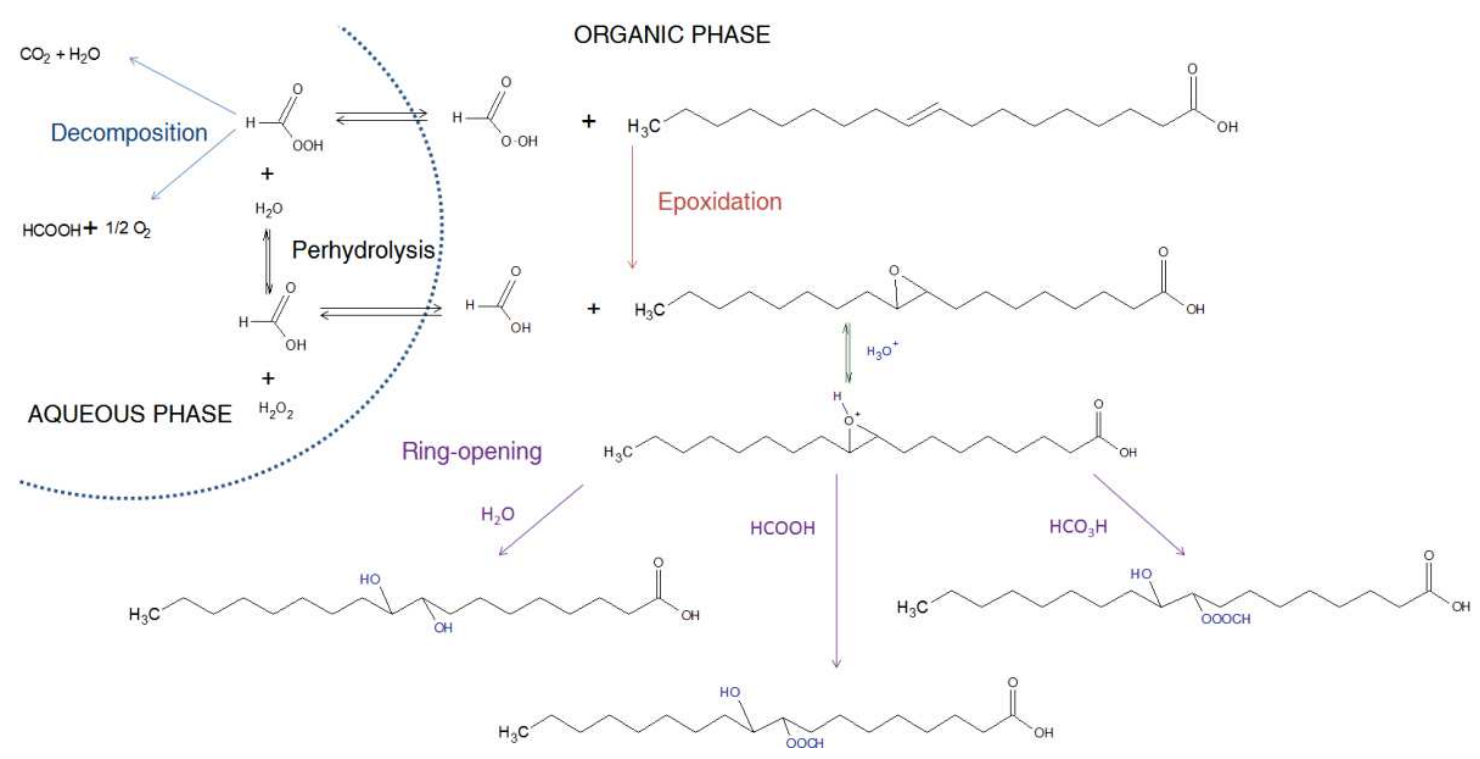

Fig. 2 - Simplified mechanism of oleic acid epoxidation by PFA.

Based on our previous research, the use of microcalorimetry (Leveneur et al., 2014b; Leveneur et al., 2015) for such a system has led to the conclusion that a semi-batch reactor should be used, and reactant accumulation should be avoided. Does the formation of PFA govern the reaction temperature? if yes, by stopping the mechanical stirring, the rate of PFA transfer from the aqueous to the organic phase diminishes and the reaction temperature could also diminish.

In the first part of the manuscript, micro-calorimetry experiments were used to determine the thermal risk in closed batch reactor, i.e., the worst case conditions. In the second part, the evolution of the heat-flow rate in the different reaction phases was determined.

The last issue was to study the influence of the time of cooling failure on the reaction temperature. The objective of this study is to illustrate the influence of different thermal mode on a complex chemical system. 


\section{Experimental section}

Microcalorimetric experiments

Experiments with Differential Scanning Calorimeter (DSC) were explained in a previous paper (Leveneur et al., 2014b). Accelerating Rate Calorimeter (ARC, Netzsch MMC 274 Nexus $\left.{ }^{\circledR}\right)$ without mixing was used. Experiments were performed under adiabatic conditions. Table 1 presents the experimental matrix for the epoxidation of oleic acid by peroxyformic acid.

Table 1. Experimental matrix for oleic acid epoxidation by peroxyformic acid in ARC with a reaction mixture mass of $2.04 \mathrm{~g}$.

\begin{tabular}{|c|c|c|}
\hline Compounds & Weight percentage & Molar percentage \\
\hline Formic acid & 16.16 & 10.56 \\
\hline Hydrogen peroxide & 12.52 & 11.07 \\
\hline Water & 45.25 & 75.60 \\
\hline Oleic acid & 26.07 & 2.77 \\
\hline
\end{tabular}

\begin{tabular}{|c|c|}
\hline Compounds & Concentration [mol/L] \\
\hline$[\mathrm{HCOOH}]_{\mathrm{aq}}$ & 5.21 \\
\hline$\left[\mathrm{H}_{2} \mathrm{O}_{2}\right]_{\mathrm{aq}}$ & 5.46 \\
\hline$\left[\mathrm{H}_{2} \mathrm{O}\right]_{\mathrm{aq}}$ & 37.29 \\
\hline$[\mathrm{OA}]_{\text {org }}$ & 3.26 \\
\hline
\end{tabular}

\section{$\underline{\text { Calorimetric reactor }}$}

The same experimental reactor system was used as described in the previous article of our group (Leveneur et al., 2014a; Zheng et al., 2016). A $300 \mathrm{~mL}$ jacketed glass reactor with a pitched blade impeller was used as illustrated by Fig. 3. Different temperature probes were placed at different locations to measure the temperature at the reaction mixture, the inlet and the outlet of the jacket. The reflux condenser was fixed at $0^{\circ} \mathrm{C}$ to avoid the evaporation of liquidphase compounds. 
Under normal conditions, heat carrier flow circulates inside the reactor jacket (jacket volume of $300 \mathrm{~mL}$ ) with a maximum volumetric rate of $8.8 \mathrm{~L} / \mathrm{min}$. Formic acid was added under semi-batch mode for $700 \mathrm{~s}$ at room temperature. The temperature mode was isoperibolic.

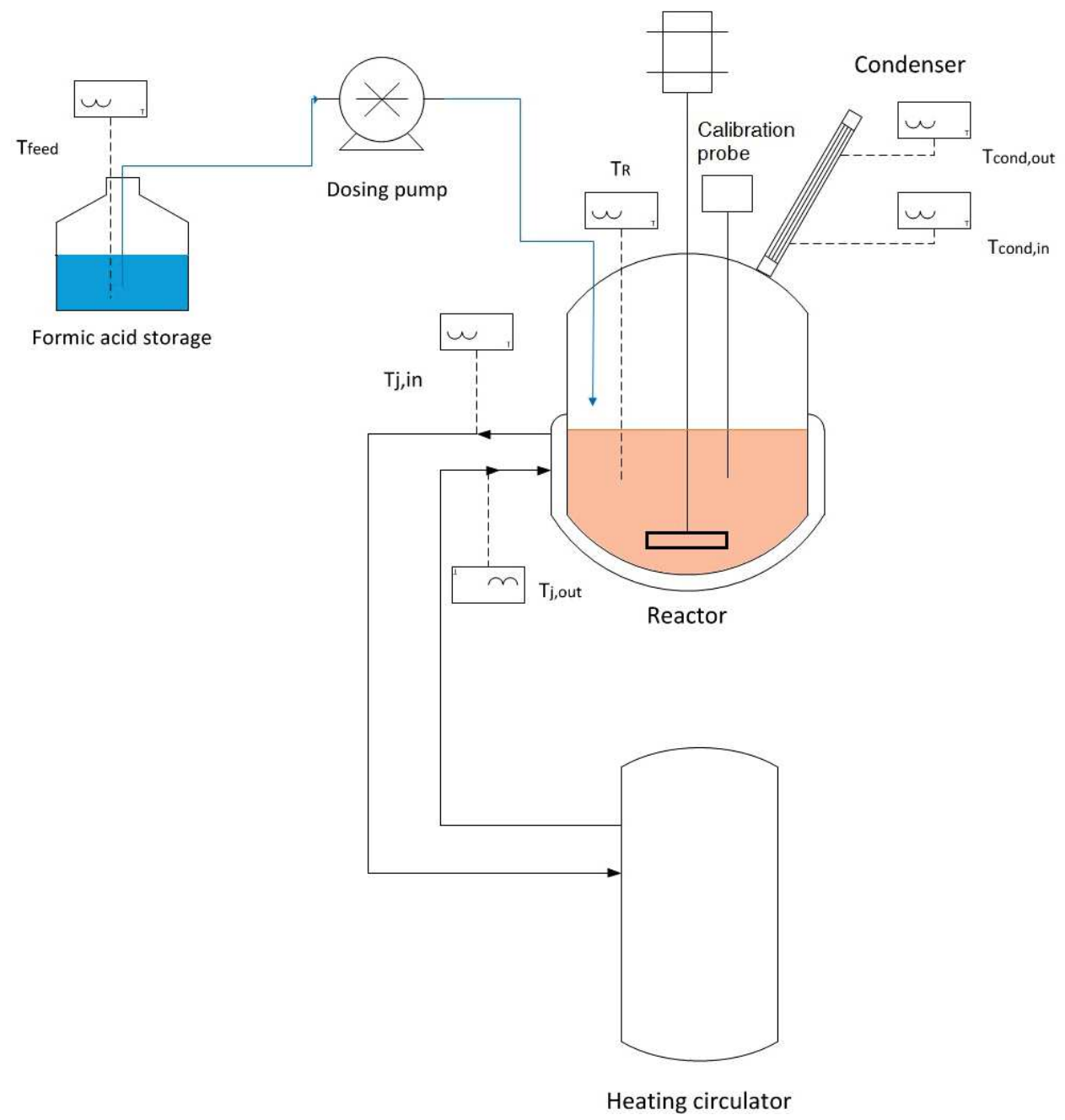

Fig. 3 - Schematic representation of the experimental setup.

Table 2 shows the experimental matrix for oleic acid epoxidation under normal conditions. Tables 3-5 summarize the experimental matrix for oleic acid epoxidation under accidents with cooling and/or stirring failure. For the sake of 
clarity, the procedures for the experiments under normal and accident conditions were explained with the results.

Table 2. Experimental matrix for oleic acid epoxidation by peroxyformic acid under normal conditions.

\begin{tabular}{|c|c|c|c|c|c|c|}
\hline Run & $\begin{array}{c}\mathrm{T}_{\mathrm{R}, 0} \\
{\left[{ }^{\circ} \mathrm{C}\right]}\end{array}$ & $\begin{array}{c}{[\mathrm{HP}]_{\mathrm{aq}, 0}} \\
{\left[\mathrm{~mol} . \mathrm{L}^{-1}\right]}\end{array}$ & $\begin{array}{c}{[\mathrm{OA}]_{\text {org }, 0}} \\
{\left[\mathrm{~mol} . \mathrm{L}^{-1}\right]}\end{array}$ & $\begin{array}{c}\mathrm{Q}_{\mathrm{FA}} \\
{\left[\mathrm{g} \cdot \mathrm{min}^{-1}\right]}\end{array}$ & $\begin{array}{c}\mathrm{V}_{\mathrm{aq}, 0} \\
{[\mathrm{~L}]}\end{array}$ & $\begin{array}{c}\mathrm{V}_{\text {org }, 0} \\
{[\mathrm{~L}]}\end{array}$ \\
\hline 1 & 50.11 & 7.90 & 3.15 & 6.78 & 0.16 & 0.14 \\
\hline 2 & 60.03 & 8.57 & 3.16 & 6.74 & 0.17 & 0.15 \\
\hline 3 & 69.70 & 8.46 & 3.19 & 6.73 & 0.17 & 0.15 \\
\hline
\end{tabular}

Table 3. Experimental matrix for oleic acid epoxidation by peroxyformic acid under cooling failure.

\begin{tabular}{|c|c|c|c|c|c|c|c|}
\hline Run & $\begin{array}{c}\mathrm{T}_{\mathrm{R}, 0} \\
{\left[{ }^{\circ} \mathrm{C}\right]}\end{array}$ & $\begin{array}{c}{[\mathrm{HP}]_{\mathrm{aq}, 0}} \\
{\left[\mathrm{~mol}_{\mathrm{L}}{ }^{-1}\right]}\end{array}$ & $\begin{array}{c}{[\mathrm{OA}]_{\mathrm{org}, 0}} \\
{\left[\mathrm{~mol}_{\mathrm{L}} \mathrm{L}^{-1}\right]}\end{array}$ & $\begin{array}{c}\mathrm{Q}_{\mathrm{FA}} \\
{\left[{\left.\mathrm{g} \cdot \mathrm{min}^{-1}\right]}\right.}\end{array}$ & $\begin{array}{c}\mathrm{V}_{\mathrm{aq}, 0} \\
{[\mathrm{~L}]}\end{array}$ & $\begin{array}{c}\mathrm{V}_{\mathrm{org}, 0} \\
{[\mathrm{~L}]}\end{array}$ & $\begin{array}{c}\text { Cooling failure period } \\
{[\mathrm{s}]}\end{array}$ \\
\hline 4 & 50.13 & 7.53 & 3.12 & 7.44 & 0.17 & 0.15 & $726-6354$ \\
\hline 5 & 60.17 & 8.13 & 3.40 & 7.02 & 0.17 & 0.14 & $702-4233$ \\
\hline 6 & 69.68 & 8.63 & 2.86 & 7.86 & 0.17 & 0.15 & $714-3705$ \\
\hline
\end{tabular}

Table 4. Experimental matrix for oleic acid epoxidation by peroxyformic acid in semi-batch calorimeter under cooling and stirring failures.

\begin{tabular}{|c|c|c|c|c|c|c|c|c|}
\hline Run & $\begin{array}{c}\mathrm{T}_{\mathrm{R}, 0} \\
{\left[{ }^{\circ} \mathrm{C}\right]}\end{array}$ & $\begin{array}{c}{[\mathrm{HP}]_{\mathrm{aq}, 0}} \\
{\left[\mathrm{~mol}_{\mathrm{L}}{ }^{-1}\right]}\end{array}$ & $\begin{array}{c}{[\mathrm{OA}]_{\mathrm{org}, 0}} \\
{\left[\mathrm{~mol}_{\mathrm{L}}{ }^{-1}\right]}\end{array}$ & $\begin{array}{c}\mathrm{Q}_{\mathrm{FA}} \\
{\left[\mathrm{g} \cdot \mathrm{min}^{-1}\right]}\end{array}$ & $\begin{array}{c}\mathrm{V}_{\mathrm{aq}, 0} \\
{[\mathrm{~L}]}\end{array}$ & $\begin{array}{c}\mathrm{V}_{\text {org }, 0} \\
{[\mathrm{~L}]}\end{array}$ & $\begin{array}{c}\text { Stirring failure period } \\
{[\mathrm{s}]}\end{array}$ & $\begin{array}{c}\text { Cooling failure period } \\
{[\mathrm{s}]}\end{array}$ \\
\hline 7 & 50.18 & 7.53 & 3.12 & 7.44 & 0.17 & 0.15 & $0-700 \mathrm{~s}$ at $100 \mathrm{rpm}$ & $700-4531$ \\
\hline 8 & 49.29 & 7.53 & 3.12 & 7.44 & 0.17 & 0.14 & $0-700 \mathrm{~s}$ at $0 \mathrm{rpm}$ & $700-4669$ \\
\hline
\end{tabular}


Table 5. Experimental matrix for oleic acid epoxidation by peroxyformic acid in case of cooling failure after formic acid addition.

\begin{tabular}{|c|c|c|c|c|c|c|c|}
\hline Run & $\begin{array}{c}\mathrm{T}_{\mathrm{R}, 0} \\
{\left[{ }^{\circ} \mathrm{C}\right]}\end{array}$ & $\begin{array}{c}{[\mathrm{HP}]_{\mathrm{aq}, 0}} \\
{\left[\mathrm{~mol}_{\mathrm{L}} \mathrm{L}^{-1}\right]}\end{array}$ & $\begin{array}{c}{[\mathrm{OA}]_{\text {org }, 0}} \\
{\left[\mathrm{~mol}_{\mathrm{L}}{ }^{-1}\right]}\end{array}$ & $\begin{array}{c}\mathrm{Q}_{\mathrm{FA}} \\
{\left[\mathrm{g} \cdot \mathrm{min}^{-1}\right]}\end{array}$ & $\begin{array}{c}\mathrm{V}_{\mathrm{aq}, 0} \\
{[\mathrm{~L}]}\end{array}$ & $\begin{array}{c}\mathrm{V}_{\text {org }, 0} \\
{[\mathrm{~L}]}\end{array}$ & $\begin{array}{c}\text { Cooling failure period } \\
{[\mathrm{s}]}\end{array}$ \\
\hline 9 & 50.00 & 7.63 & 3.17 & 6.72 & 0.17 & 0.14 & $700-1300$ \\
\hline 10 & 50.00 & 7.62 & 3.17 & 6.92 & 0.17 & 0.15 & $700-1600$ \\
\hline
\end{tabular}




\section{Results and discussion}

3.1 Thermal risk assessment based on micro-calorimetry results

The following safety criteria: $\mathrm{T}_{\mathrm{D} 24}$, Maximum Temperature for Synthesis Reactions (MTSR), Maximum Temperature for Technical reason (MTT), TMR ad and $\Delta \mathrm{T}_{\text {ad }}$ were calculated or measured (Stoessel, 2008). The work presented in this section follows the same methodology as presented by Leveneur et al. (2015), and completes the previous study of Leveneur et al. (2014b).

During the epoxidation of vegetable oils by peroxyformic acid, even at low process temperature, secondary reactions due to decomposition of PFA into gaseous product can occur (Leveneur et al., 2012). Thus, at process temperature, it is not possible to segregate synthesis reactions producing liquid products from decomposition reactions producing gaseous products. For that reason, MTSR was not calculated for this system.

From DSC experiments, the total adiabatic temperature rise $\Delta T_{\text {ad,tat }}$ was calculated to be $1000^{\circ} \mathrm{C}$ for oleic acid epoxidation by peroxyformic acid (Leveneur et al., 2014b). It should be kept in mind that this value represents the total energy released by chemical reactions including hydrogen peroxide decomposition divided by the heat capacity of the reaction mixture. 


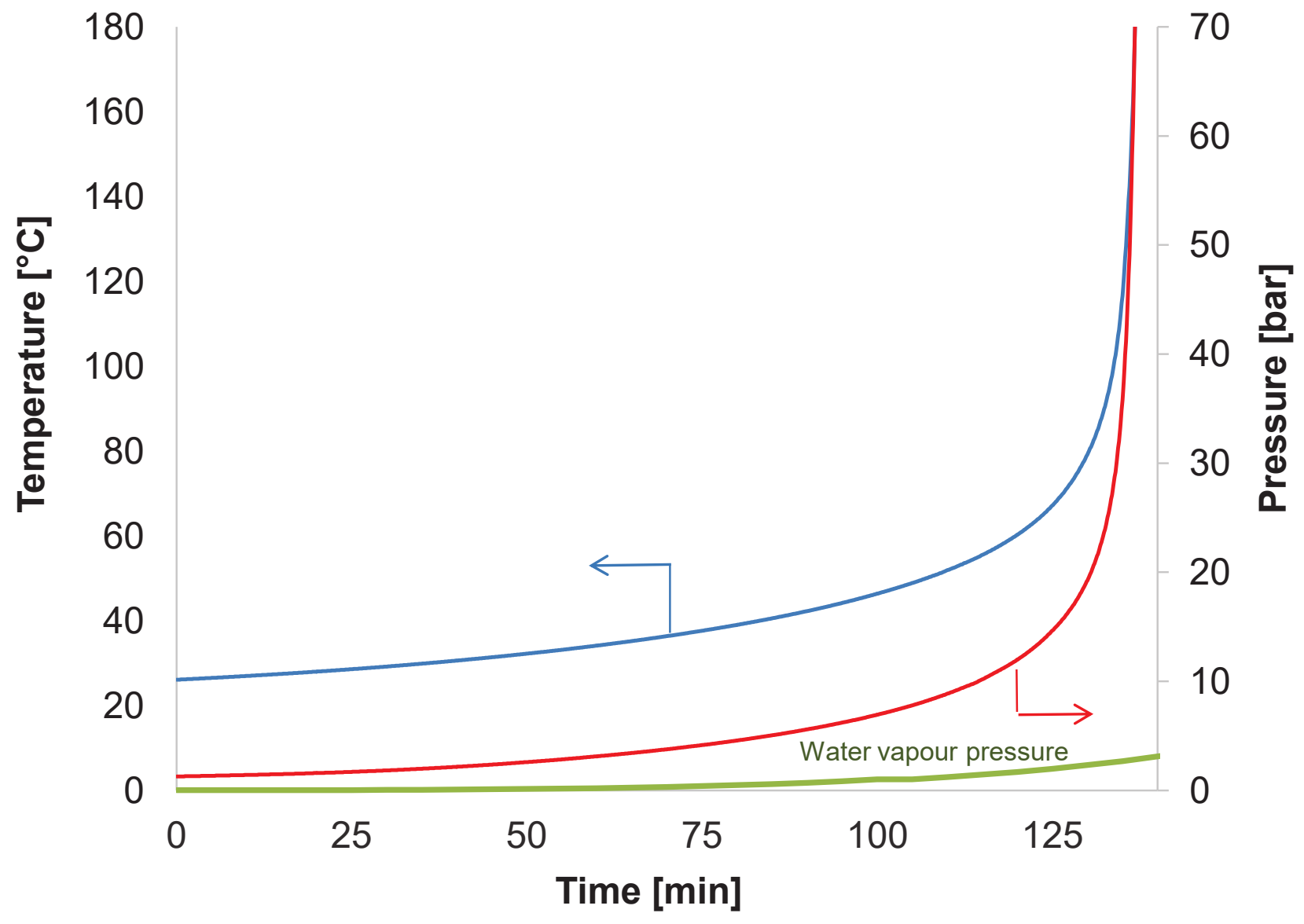

Fig. 4 - ARC for epoxidation of oleic acid by PFA at $\varphi=1.87$.

Safety criteria linked to kinetics, i.e., $\mathrm{TMR}_{\mathrm{ad}}$ and $\mathrm{T}_{\mathrm{D} 24}$, can be calculated from ARC experiments (Fig. 4). Thermal inertia of the system should be taken into account by using the $\varphi$-factor number (ca. 1.87), defined as $\varphi=\frac{m_{R} \cdot \hat{C}_{P_{R}}+m_{\text {cell }} \cdot \hat{C}_{P_{\text {cell }}}}{m_{R} \cdot \hat{C}_{P_{R}}}$

Graphs of Fig. 4 show the presence of a thermal runaway leading to a pressure increase due to the presence of secondary reactions, i.e., decomposition of peroxides. The equilibrium water vapor pressure curve shows that the pressure increase is linked to the presence of gas released by secondary reactions. 
By taking into account the thermal inertia of the system, it is possible to determine the safety criteria obtained by DSC and ARC (Table 6).

Table 6. Safety criteria for oleic acid epoxidation by PFA.

\begin{tabular}{|c|c|c|}
\cline { 2 - 3 } \multicolumn{1}{c|}{} & Epoxidation by PFA & Comments \\
\hline $\mathrm{T}_{\text {final }} /{ }^{\circ} \mathrm{C}$ & 1070 & Obtained from DSC \\
\hline $\mathrm{MTT} /{ }^{\circ} \mathrm{C}$ & 100 & \\
\hline $\mathrm{T}_{\mathrm{p}} /{ }^{\circ} \mathrm{C}$ & 70 & Obtained from ARC \\
\hline $\mathrm{T}_{\mathrm{D} 24} /{ }^{\circ} \mathrm{C}$ & -17.4 & Obtained from ARC \\
\hline $\mathrm{T}_{\mathrm{D} 8} /{ }^{\circ} \mathrm{C}$ & 1.2 & Obtained from DSC \\
\hline$\Delta \mathrm{T}_{\text {ad, total }} /{ }^{\circ} \mathrm{C}$ & 1000 & Obtained from ARC \\
\hline $\mathrm{TMR}_{\text {ad, total }}\left(70^{\circ} \mathrm{C}\right) / \mathrm{min}$ & 23.30 & \\
\hline
\end{tabular}

$T_{D 24}$ is lower than the normal process temperature and the adiabatic temperature rise is high. Thus, this system should not be performed in a closed batch system. The main issue of this chemical system is the control of temperature to avoid the pressure increase due to the formation of gaseous products. 


\subsection{Reaction calorimeter}

According to section 3.1, it was found that the production of epoxidized oleic acid by PFA should not be performed in batch mode.

A classical question asked to a student audience during a heat transfer lecture: "In case of cooling failure, should we stop the mechanical agitation in a batch reactor to avoid a thermal runaway accident?" The majority of students thinks that by stopping the mechanical stirrer the reaction will stop, and thus the risk of thermal runaway diminish. This logics is wrong, because reaction continues to progress with a certain kinetics, and the heat exchanged between reaction mixture and cooling system strongly diminishes.

This approach could be different for the epoxidation of vegetable oils by PFA because it is a multiphasic system. Indeed, by stopping the agitation, the mass transfer kinetics of PFA from aqueous to organic phase is diminished. Consequently, the rate of epoxidation could slow down which would diminish the heat-flow rate released by the reaction, and also the temperature of the reaction mixture.

The following scenarii were studied:

- Cooling failure without stirring failure after the total addition of formic acid,

- Cooling failure with stirring failure or low agitation after the total addition of formic acid,

- Influence of cooling failure period. 


\subsubsection{Reactor thermal characterization}

To illustrate the complexity of the system, it is important to describe the mass and energy balances.

The energy balance for a chemical reactor can be expressed as:

$\left\{\begin{array}{l}\text { Rate of accumulati on of energy } \\ \text { within the reaction liquid phase }\end{array}\right\}=\left\{\begin{array}{l}\text { Heat flow into } \\ \text { the reactor wi th reactants }\end{array}\right\}+\left\{\begin{array}{l}\text { Heat generated/ absorbed } \\ \text { by reaction }\end{array}\right\}$ $-\left\{\begin{array}{l}\text { Heat exchange with } \\ \text { surroundin gs }\end{array}\right\}$

In other term, we obtain

$$
\begin{aligned}
&\left\{\mathrm{q}_{\mathrm{acc}}\right\}=\left\{\mathrm{q}_{\text {dosing }}\right\}+\left\{\mathrm{q}_{\text {reactions }}\right\}-\left\{\mathrm{q}_{\text {exchange to heat carrier }}+\mathrm{q}_{\text {loss }}\right\} \\
& \mathrm{m}_{\mathrm{R}} \cdot \hat{\mathrm{C}}_{\mathrm{PR}} \frac{\mathrm{dT}_{\mathrm{R}}}{\mathrm{dt}}=[\mathrm{FA}]_{\text {feed }} \cdot \mathrm{Q}_{\mathrm{FA}} \cdot \rho_{\mathrm{FA}} \cdot \hat{\mathrm{C}}_{\mathrm{P}}(\mathrm{FA}) \cdot\left(\mathrm{T}_{\text {feed }}-\mathrm{T}_{\mathrm{R}}\right) \\
&-\left(\mathrm{r}_{\text {perh }} \cdot \Delta \mathrm{H}_{\mathrm{R}_{\text {perh }}}+\mathrm{r}_{\text {decomp }, 1} \cdot \Delta \mathrm{H}_{\mathrm{R}_{\text {decomp }, 1}}+\mathrm{r}_{\text {decomp }, 2} \cdot \Delta \mathrm{H}_{\mathrm{R}_{\text {decomp }, 2}}\right) \mathrm{V}_{\mathrm{aq}} \\
&-\left(\mathrm{r}_{\text {Epoxidation }} \cdot \Delta \mathrm{H}_{\mathrm{R}_{\text {Epoxidatio }}}+\left(\mathrm{r}_{\mathrm{ROW}}+\mathrm{r}_{\mathrm{ROFA}}+\mathrm{r}_{\mathrm{ROPFA}}\right) \cdot \Delta \mathrm{H}_{\mathrm{R}_{\mathrm{RO}}}\right) \mathrm{V}_{\mathrm{org}} \\
&-\mathrm{UA} \cdot\left(\mathrm{T}_{\mathrm{R}}-\mathrm{T}_{\mathrm{J}}\right)-\beta \cdot \sum x_{i} \cdot P_{i}
\end{aligned}
$$

The term $\mathrm{q}_{\mathrm{acc}}$ states for the rate of energy accumulation within the reaction mixture. The term $m_{R}$ is the mass of the reaction mixture, $\hat{C}_{P_{R}}$ is constantpressure specific heat capacity of the reaction mixture and $T_{R}$ is the reaction temperature. The heat capacity can be expressed as:

$$
\hat{\mathrm{C}}_{\mathrm{P}_{\mathrm{R}}}=\sum_{i=1}^{N} w_{i} \cdot \hat{\mathrm{C}}_{\mathrm{P}_{\mathrm{i}}}
$$

where $\mathrm{w}_{\mathrm{i}}$ and $\hat{\mathrm{C}}_{\mathrm{P}_{\mathrm{i}}}$ are weight percent and specific heat capacity of compound $i$. 
By using a Tian-Calvet calorimeter (Zheng et al., 2016), the specific heat capacity of oleic acid and oleic acid ring-opening products were measured to be 1.95 and $2.80 \mathrm{~J} . \mathrm{g}^{-1} \cdot \mathrm{K}^{-1}$, respectively within the temperature range of $40-70^{\circ} \mathrm{C}$. The term $\mathrm{q}_{\text {dosing }}$ is the rate of energy entering system by inflow. The term $\mathrm{q}_{\text {reactions }}$ is the heat generated by the chemical reactions. The term $\mathrm{q}_{\text {loss }}$ is the heat-flow loss.

The heat-flow exchanged between the reaction mixture and the heat carrier flow

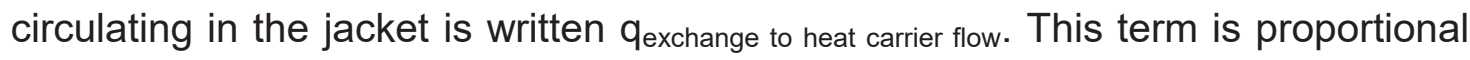
to the product $U A$, with $U$ the overall heat transfer coefficient and $A$ the heat transfer area, and $\mathrm{T}_{\mathrm{j}}$ is heat carrier fluid temperature located in the reactor jacket. The overall heat transfer coefficient $(U)$ can evolve during the reaction course, and can be expressed as a sum of thermal resistances such as

$$
\frac{1}{U}=\frac{1}{h_{R}}+\frac{d_{W}}{\lambda_{W}}+\frac{1}{h_{j}}
$$

where, $\frac{1}{h_{R}}$ and $\frac{1}{h_{j}}$ represent the convective resistance to the heat transfer from the reaction side and jacket side, respectively; $d_{w}$ is the thickness of the glass wall between reaction mixture and the heat carrier fluid, and $\lambda_{w}$ is the heat conductivity of the glass wall. Eq. 4 was obtained by using the thin wall approximation. The Wilson plot analysis was used to determine these parameters at different temperatures and chemical compositions. 
The term $\frac{1}{\mathrm{~h}_{\mathrm{R}}}$ can change during the reaction, and the term $\frac{1}{\mathrm{~h}_{\mathrm{j}}}+\frac{d_{w}}{\lambda_{w}}$ can be merged to a constant and noted by $\frac{1}{\varphi_{\mathrm{R}}}$. Eq. (4) becomes now:

$\frac{1}{U}=\frac{1}{h_{R}}+\frac{1}{\varphi_{R}}$

Under isothermal conditions and in the absence of chemical reactions, the properties of the fluid and geometrical factors are constant. Both of these conditions are fulfilled during the electrical calibration phase, thus the internal heat transfer coefficient can be expressed as

$\mathrm{h}_{\mathrm{R}}=\mathrm{C}^{\prime} \cdot \mathrm{N}^{\mathrm{a}}$

with $C^{\prime}=C \cdot \frac{d_{s}^{2 a}}{D_{i}} \cdot \rho_{R}^{a} \cdot \hat{C}_{p_{R}}^{b} \cdot \lambda_{R}^{1-b} \cdot \eta_{R}^{b-a}$

After some simplification, Eq.(6) transforms to

$\frac{1}{U}=\frac{1}{C^{\prime}} \cdot N^{-a}+\frac{1}{\varphi_{R}}$

In case of stirred tank reactor, the value of the parameter a is $2 / 3$. By plotting $1 / \mathrm{U}$ versus $\mathrm{N}^{-2 / 3}$, a straight line should be obtained if the model is valid. To carry out such measurements, different experiments with oleic acid, epoxidized oleic acid and ring-opening products from oleic acid were performed (Fig. 5). 


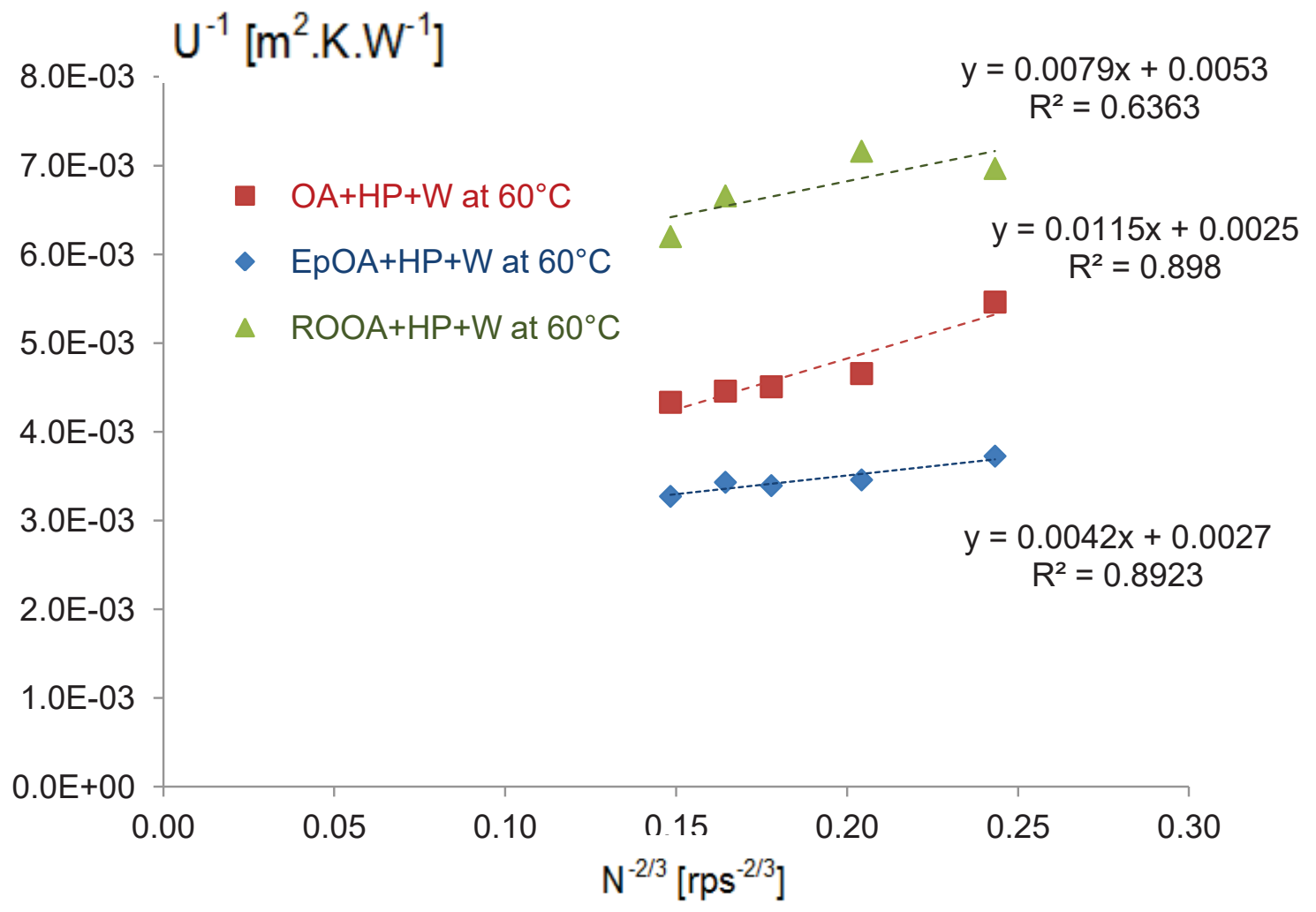

Fig. 5 - Evolution of $1 / \mathrm{U}$ at $60^{\circ} \mathrm{C}$.

As described by Campanella et al. (2010), epoxidized and ring-opening products are thixotropic fluid meaning that their viscosities vary with the rotating speed. The aqueous phase and the fresh oleic acid organic phase can be considered as a Newtonian fluid. As the unsaturation group is converted to epoxide or to ringopening product, then the relation between $\mathrm{U}^{-1}$ and $\mathrm{N}^{-2 / 3}$ is not linear.

The resistance term $\frac{1}{\varphi_{\mathrm{R}}}$ should be constant for the different experiments because it is linked to reactor and heat-carrier fluid properties. This parameter does not evolve during the process under normal conditions. It was calculated to be $\varphi_{R}=400 \mathrm{~W} \cdot \mathrm{m}^{-2} \cdot \mathrm{K}^{-1}$. This parameter was measured at $80^{\circ} \mathrm{C}$, and the same value was obtained. 
Based on this result and the models developed previously by our group (Leveneur et al., 2014a; Zheng et al., 2016), we have simulated the experiments corresponding to the initial experimental conditions of Run 3. Supplementary information gives into details the derivation of mass and energy balances and the simulation method (S1).

Figs $6 \mathrm{~A}-\mathrm{C}$ present the results of the simulation. The heat-flow rate of the reactions from the organic phase is higher than the reactions from the aqueous phase (Fig. 6 A).

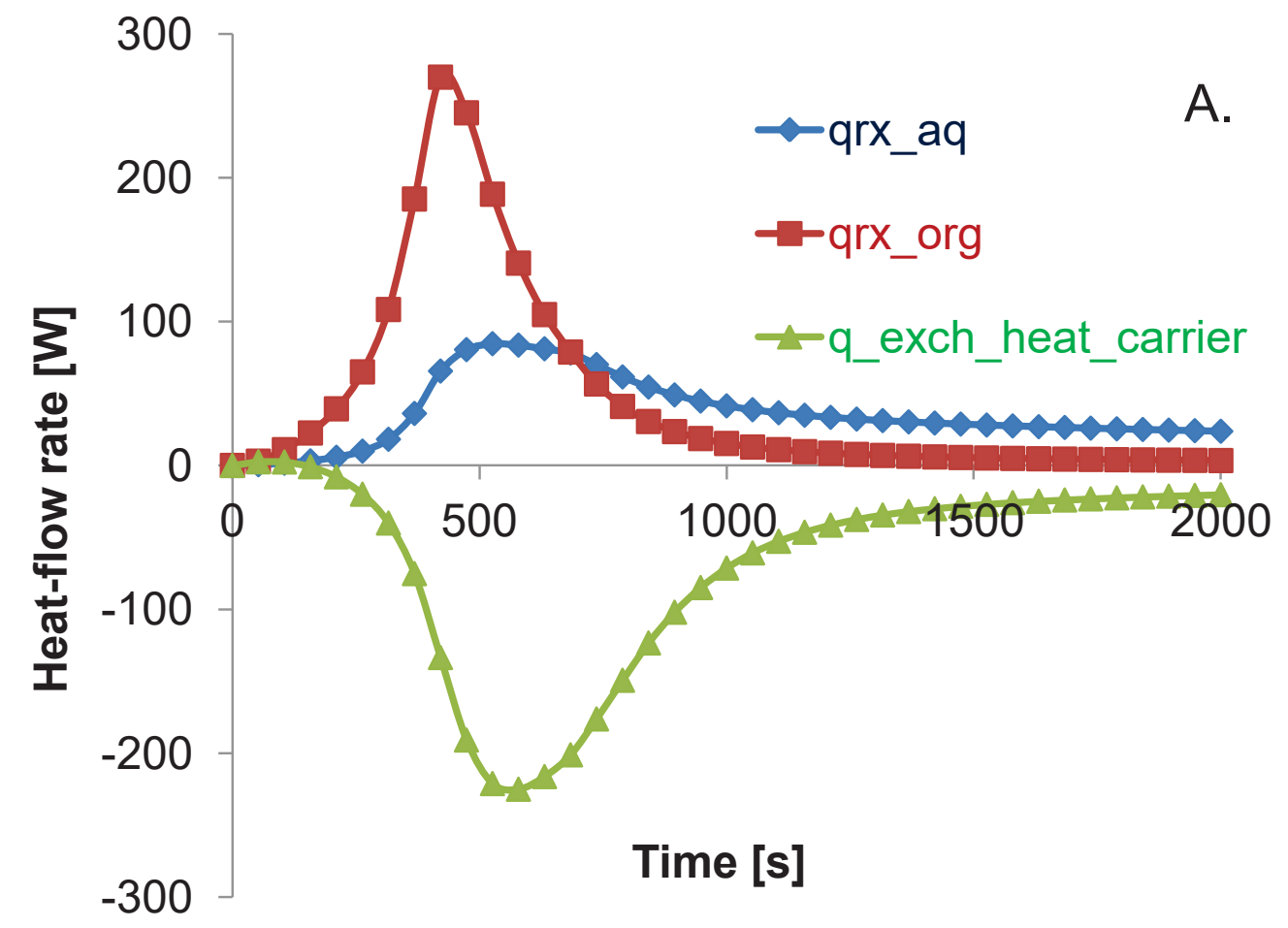



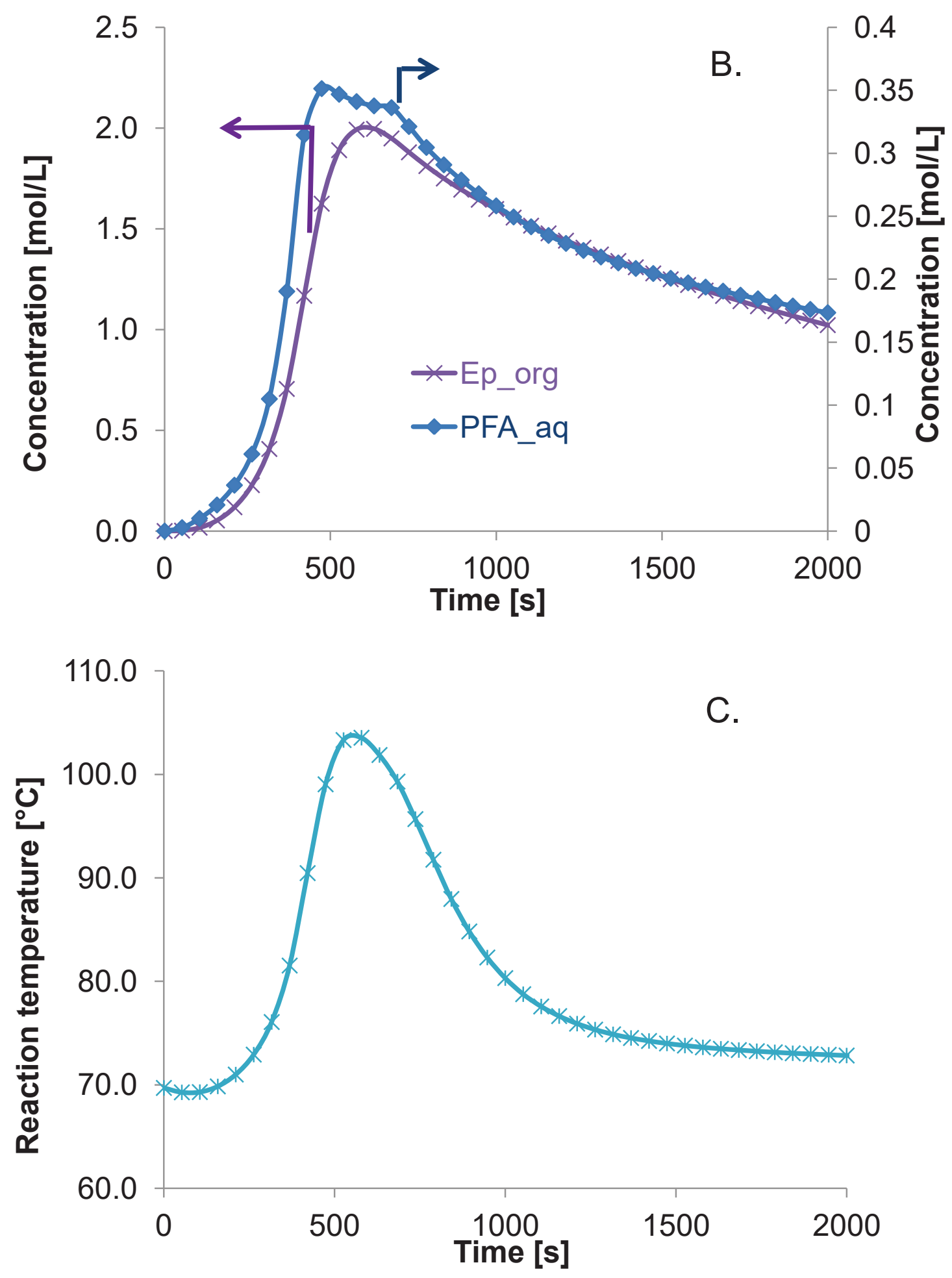

Fig. 6 - Simulation of oleic acid epoxidation by PFA with initial experimental condition of Run 3. 
Based on this simulation, the PFA production governs the heat-flow rate of the reactions in aqueous and organic phases. The heat-flow rates of the reactions occurring in the organic phase (epoxidation and ring-opening reactions) is higher than the heat-flow rate of the reactions occurring in the aqueous phase (perhydrolysis and decomposition). Thus, one could expect that in case of a stirring failure accident, the heat-flow rate of reactions from the organic phase could diminish. If this hypothesis is correct, then it would be better to stop the stirring in case of cooling failure. For safety reasons, we wanted to check such assumption on a lab-scale reactor. 
3.2.2 Cooling failure without agitation failure after the total addition of formic acid

The following safety criteria for the laboratory-scale reactor were measured: maximum reaction temperature $T_{R \max }$ and time to maximum reaction temperature $t_{\max }$. The maximum temperature for technical reason can be the boiling point of the reaction mixture.

In a first step, oleic acid, hydrogen peroxide and water were added into the reactor under agitation. When the desired initial temperature was reached, formic acid solution was added with a mass flow rate of $7 \mathrm{~g} \cdot \mathrm{min}^{-1}$ for $700 \mathrm{~s}$. When all the formic acid solution had been added, the heat carrier fluid circulation inside the reactor jacket was stopped. Fig. 7 shows a schematic view of the process.

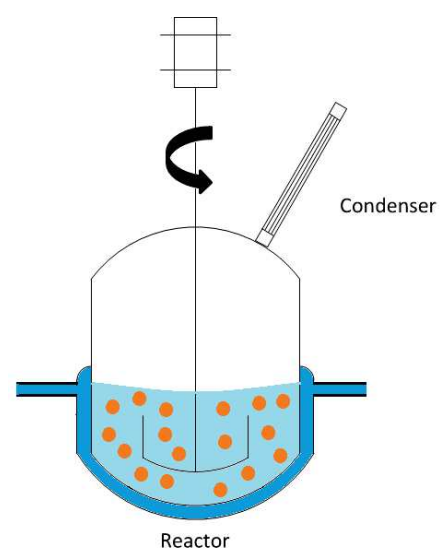

Step 1. System under agitation (650 rpm) \& isoperibolic mode Mixture of hydrogen peroxide, water and oleic acid heated to the desired temperature.

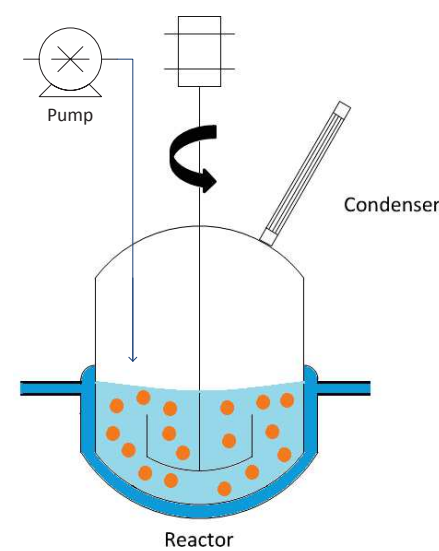

Step 2. System under agitation (650 rpm) \& isoperibolic mode Addition of formic acid at 7 g. $\mathrm{min}^{-1}$ for $700 \mathrm{~s}$.

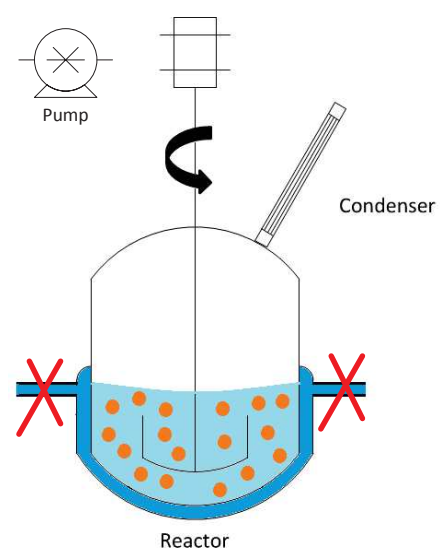

Step 3. System under agitation $650 \mathrm{rpm})$

Cooling failure after formic acid addition

Fig. 7 - Schematic view of cooling failure accident with $[\mathrm{OA}]_{0, \mathrm{org}} \approx 3.12 \mathrm{~mol} . \mathrm{L}^{-1}$ and

$$
\left[\mathrm{H}_{2} \mathrm{O}_{2}\right]_{0, \mathrm{aq}} \approx 8 \mathrm{~mol} \cdot \mathrm{L}^{-1} \text {. }
$$


Figs. $8 \mathrm{~A}-\mathrm{C}$ show the evolution of the jacket and reaction temperatures under normal and accidental conditions for Runs 1-6.

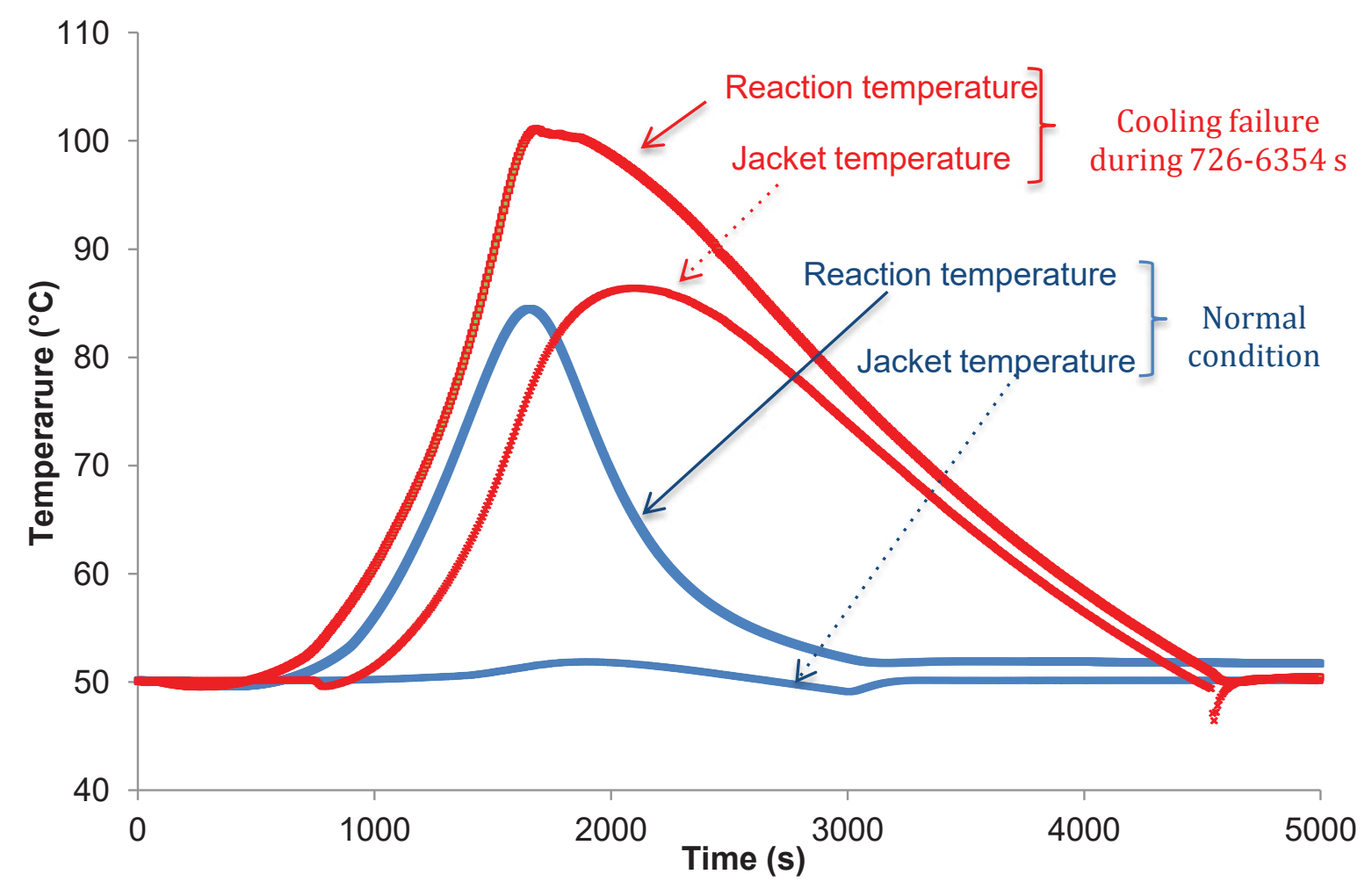

Fig. 8.A - Evolution of jacket and reaction temperature for Runs $1 \& 4$. 


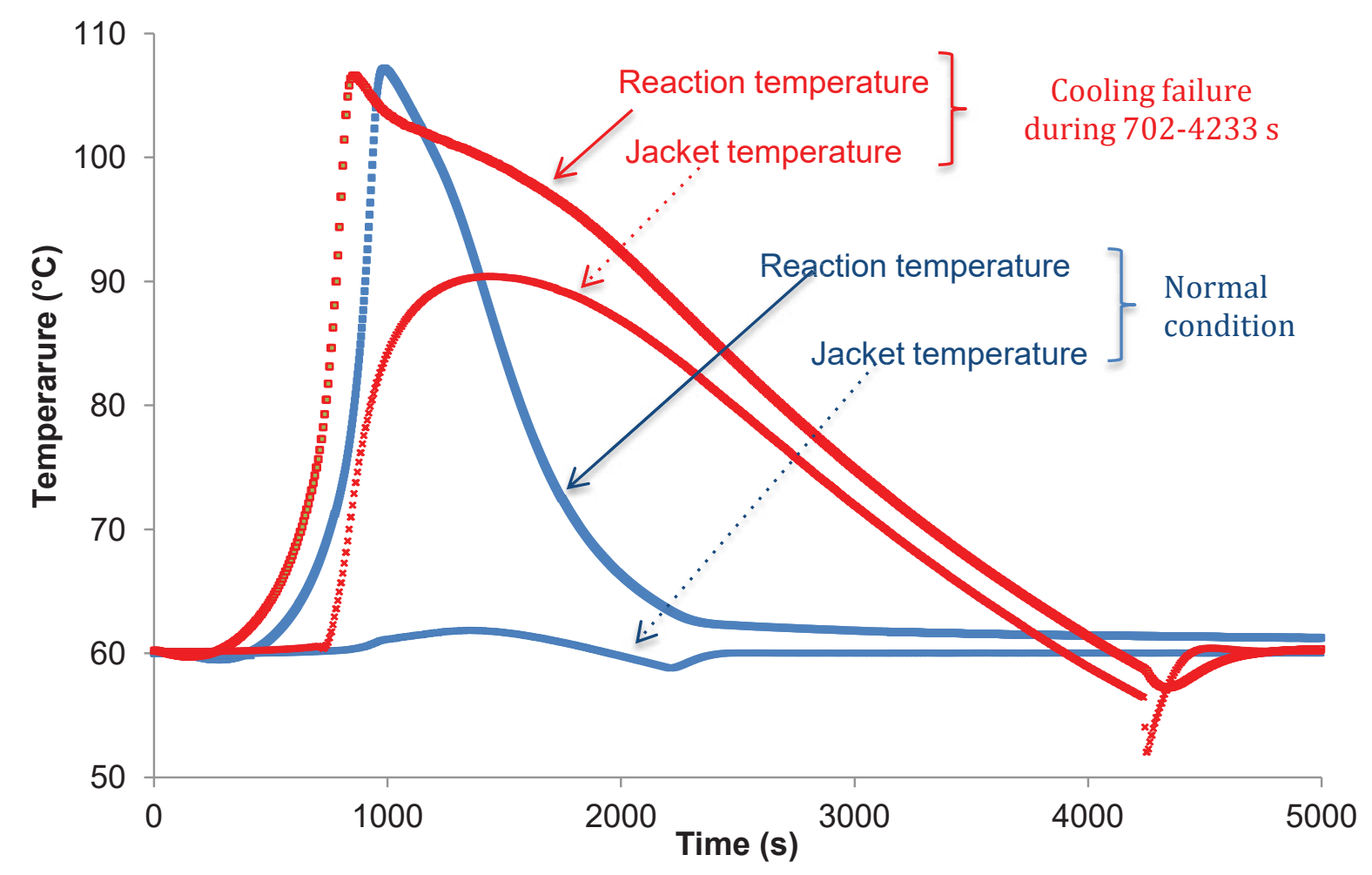

Fig. 8.B - Evolution of jacket and reaction temperature for Runs 2 \& 5 . 


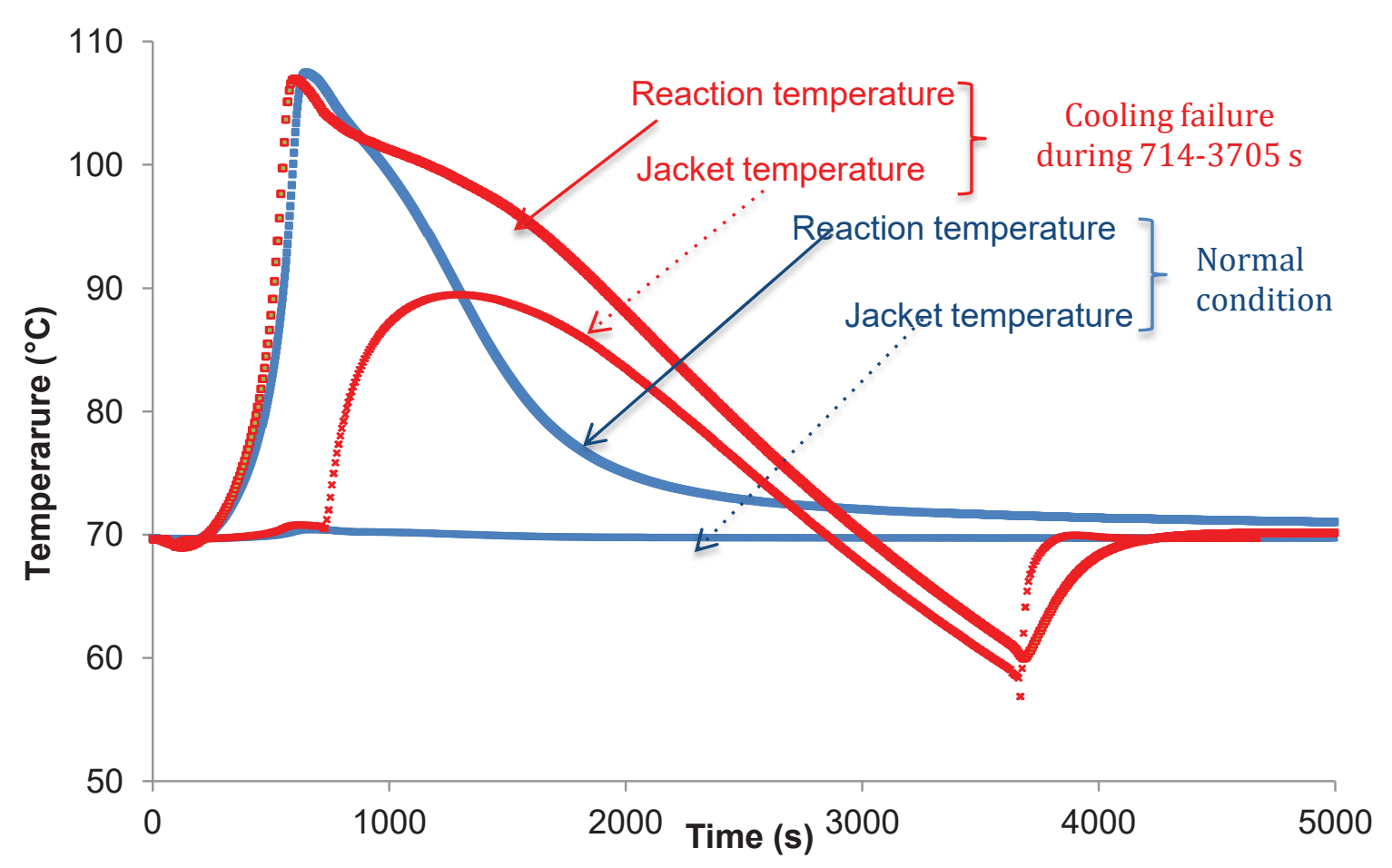

Fig. 8.C - Evolution of jacket and reaction temperature for Runs 3 \& 6 .

From Figs. $8 \mathrm{~A}-\mathrm{C}$, it can be noticed that in case of cooling failure, the system shifts from isoperibolic to a pseudo-adiabatic stage. Indeed, in case of adiabatic condition the jacket temperature would have followed the reaction temperature. One could observe that the system reach a maximum temperature corresponding to the boiling point of the reaction mixture. Table 7 summarizes the results of time to reach the maximum temperature $t_{\max }$ and maximum temperature $T_{R \max }$. 
Table 7. Safety criteria $t_{\max }$ and $T_{\max }$.

\begin{tabular}{|c|c|c|c|}
\hline Run & $\begin{array}{c}\text { Initial reaction } \\
\text { temperature }\left({ }^{\circ} \mathrm{C}\right)\end{array}$ & $\mathrm{t}_{\max }(\mathrm{s})$ & $\mathrm{T}_{\mathrm{Rmax}}\left({ }^{\circ} \mathrm{C}\right)$ \\
\hline 1 & 50.11 & 1653 & 84.46 \\
\hline 2 & 60.03 & 986 & 107.16 \\
\hline 3 & 69.70 & 648 & 107.47 \\
\hline 4 & 50.13 & 1683 & 101.08 \\
\hline 5 & 60.17 & 855 & 106.61 \\
\hline 6 & 69.68 & 597 & 106.97 \\
\hline
\end{tabular}

From Table 7 , the time to reach the maximum temperature $t_{\max }$ is similar under normal and under cooling failure conditions. It can be noticed that when initial reaction temperature is $50^{\circ} \mathrm{C}$, the maximum reaction temperature is higher in case of cooling failure. When the initial reaction temperature is higher than $60^{\circ} \mathrm{C}$, then the maximum reaction temperature corresponds to the boiling point of the reaction mixture, ca. $106^{\circ} \mathrm{C}$. This maximum temperature cannot be overtaken.

The safety criterion MTT is often the boiling point of the reaction mixture. From Table 5, it was defined to $100^{\circ} \mathrm{C}$, which is the normal boiling point of water. From the experiment carried out in a semi-batch reactor equipped with a condenser, the boiling point was ca. $106^{\circ} \mathrm{C}$, which is not different from the previous one. In the presence of the condenser, the reaction temperature cannot be higher than the boiling point, which can be used as a safety barrier. 
From the microcalorimetric results, the time to maximum rate under adiabatic conditions was measured to be ca. $162 \mathrm{~s}$, which is shorter than the one obtained from laboratory-scale reactor in case of cooling failure, i.e., ca. $600 \mathrm{~s}$. This is due to the fact that results obtained from DSC and ARC are valid under adiabatic conditions and for a batch system. For a semi-batch reactor under isoperibolic mode with a reflux condenser, in case of cooling failure the system shift to a pseudo-adiabatic system where evaporation, condensation and energy loss act as a safety barrier diminishing the thermal risk. 
3.2.3 Cooling failure with agitation failure or low agitation after total addition of formic acid

For this liquid-liquid reaction system, mixing is an important issue for mass and heat transfer. Furthermore, these two transport phenomena issues are closely linked. As illustrated by Figs. 6, the heat-flow rate of reactions from the organic phase is higher than reactions from the aqueous phase. The effect of the rotating speed on the reaction temperature was studied. The goal of such experiment was to obtain the maximum accumulation of oxidizing compounds.

To have the worst-case scenario, stirring was stopped during the addition period to allow a maximum accumulation of the reactants under isoperibolic mode. Then, the stirring was restarted and cooling failure occurred. Fig. 9 illustrates this scenario.

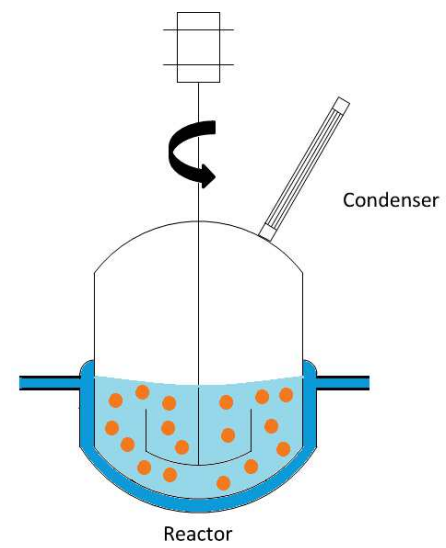

Step 1. System under agitation (650 rpm) \& isoperibolic mode Mixture of hydrogen peroxide, water and oleic acid heated to the desired temperature.

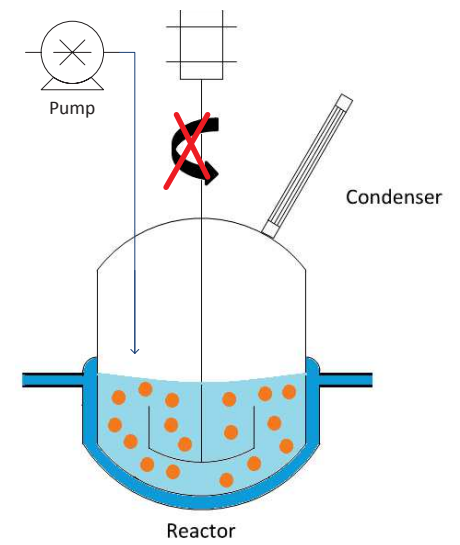

Step 2. System isoperibolic mode Addition of formic acid at $7 \mathrm{~g} \cdot \mathrm{min}^{-1}$ for $700 \mathrm{~s}$.

During the addition, stirring failure

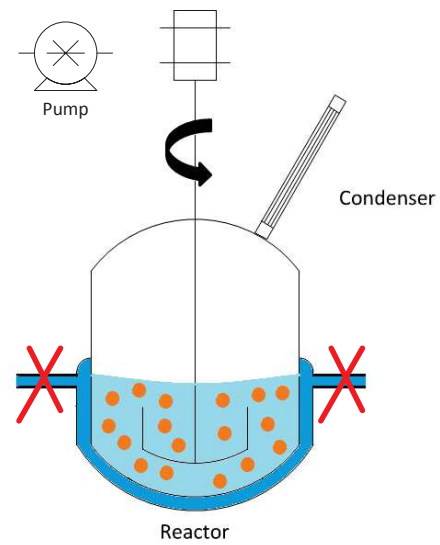

Step 3. System under agitation (650 rpm) Cooling failure after formic acid addition

Fig. 9 - Schematic view of cooling failure accident with $[A O]_{0, \text { org }} \approx 3.12 \mathrm{~mol}^{-\mathrm{L}^{-1}}$ $\left[\mathrm{H}_{2} \mathrm{O}_{2}\right]_{0, \mathrm{aq}} \approx 8 \mathrm{~mol} . \mathrm{L}^{-1}$ and initial temperature of $50^{\circ} \mathrm{C}$. 
As illustrated by Fig. 9, a stirring failure during the addition of formic acid into the reaction mixture was demonstrated. Two experiments were performed under same experimental conditions but with different rotating speeds, i.e., 0 and 100 rpm.

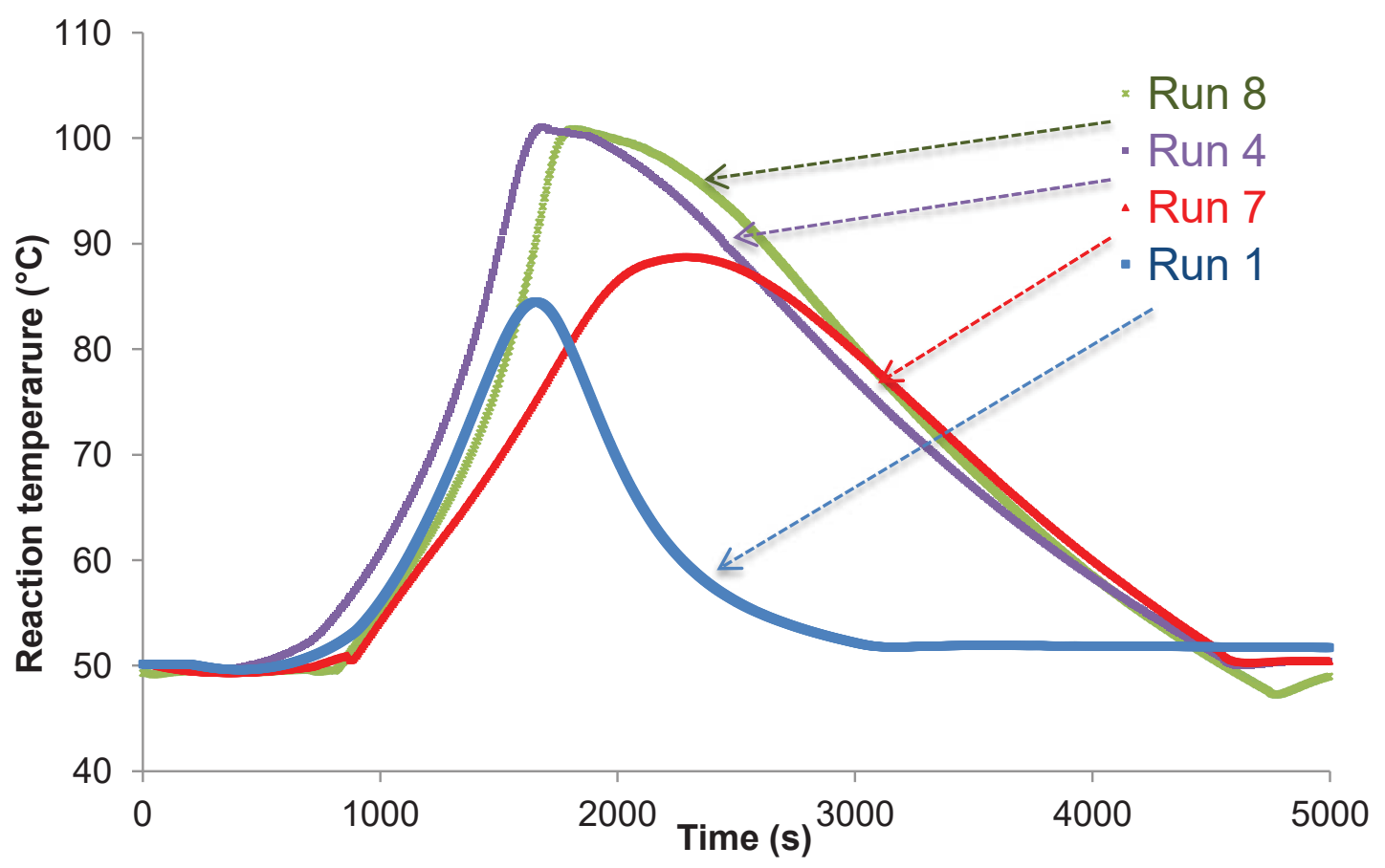

Fig. 10 - Evolution of reaction temperature for runs $1,4,7$ \& 8 .

Table 8. Safety criteria for runs 1, 4, $7 \& 8$.

\begin{tabular}{|c|c|c|c|c|}
\hline Run & $\begin{array}{c}\text { Initial reaction } \\
\text { temperature }\left({ }^{\circ} \mathrm{C}\right)\end{array}$ & $\mathrm{t}_{\max }(\mathrm{s})$ & $\mathrm{T}_{\max }\left({ }^{\circ} \mathrm{C}\right)$ & Characteristic \\
\hline 1 & 50.11 & 1653 & 84.46 & Normal condition \\
\hline 4 & 50.13 & 1683 & 101.08 & Cooling failure \\
\hline 7 & 50.18 & 2286 & 88.75 & $\begin{array}{c}\text { Cooling failure \& } \\
\text { low stirring }\end{array}$ \\
\hline 8 & 49.29 & 1812 & 100.87 & $\begin{array}{c}\text { Cooling \& stirring } \\
\text { failure }\end{array}$ \\
\hline
\end{tabular}


Run 4 (only cooling failure) and Run 8 (cooling failure and no agitation during the addition stage) were the two worst case scenario (Fig. 10). The maximum reaction temperature corresponded at the boiling point of the reaction mixture (Table 8). In the case of Run 8 , a minor shift for the safety criteria $t_{\max }$ was noticed.

Stirring plays an important role on the mass transfer and particularly on the PFA mass transfer but also on the heat transfer (Fig. 5). By stopping the rotating speed, heat-flow rate from organic phase might diminish but also heat transfer from reaction mixture to the heat carrier fluid. Run 7 shows that it is better to maintain the rotating speed to allow heat transfer between the reaction mixture and the heat carrier circulating in the reactor jacket.

\subsubsection{Time of no return}

The goal of these experiments was to evaluate the time of cooling failure on the reaction temperature. Two experiments under similar initial conditions (Runs 9 and 10) were carried out but the time of the cooling failure after the FA addition was different.

In a first step oleic acid, hydrogen peroxide and water were added into the reactor under agitation. As the desired initial temperature was reached, formic acid solution was added with a mass flow rate of $7 \mathrm{~g} \cdot \mathrm{min}^{-1}$ for $700 \mathrm{~s}$. When all the formic acid solution was poured, the heat carrier circulation inside the reactor 
jacket was stopped for a short time period. Fig. 11 shows a schematic view of the process.

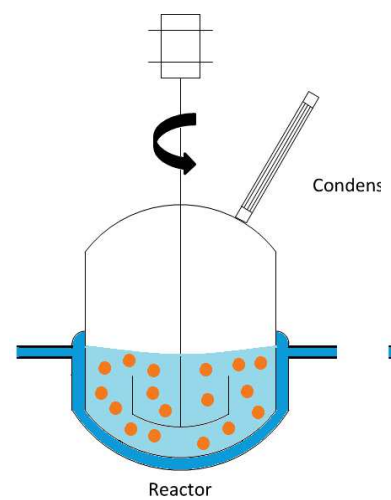

Step 1. System under agitation (650 rpm) \& isoperibolic mode Mixture of hydrogen peroxide, water and oleic acid heated to the desired temperature.

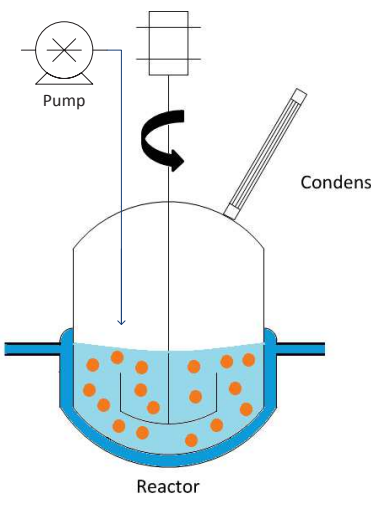

Step 2. System isoperibolic mode Addition of formic acid at 7 g. $\min ^{-1}$ for $700 \mathrm{~s}$

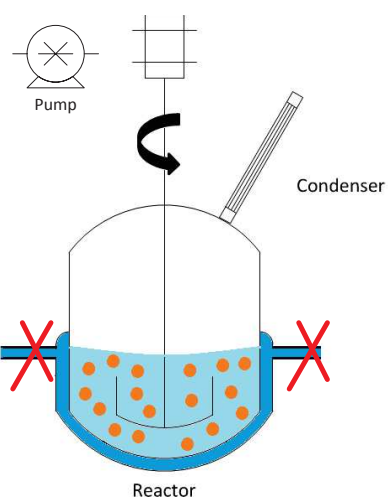

Step 3. System under agitation $650 \mathrm{rpm})$

Cooling failure after formic acid addition

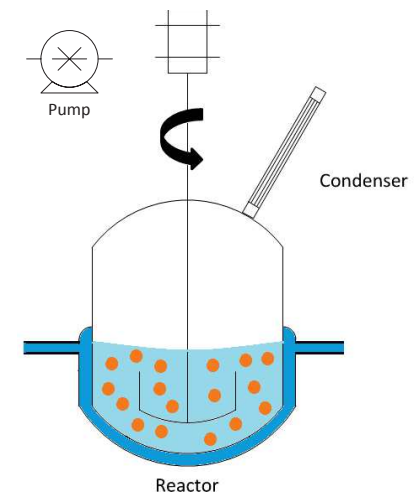

Step 4. System under agitation (650 rpm)

Heat carrier flow restart

Fig. 11 - Schematic view of cooling failure accident for Runs $9 \& 10$.

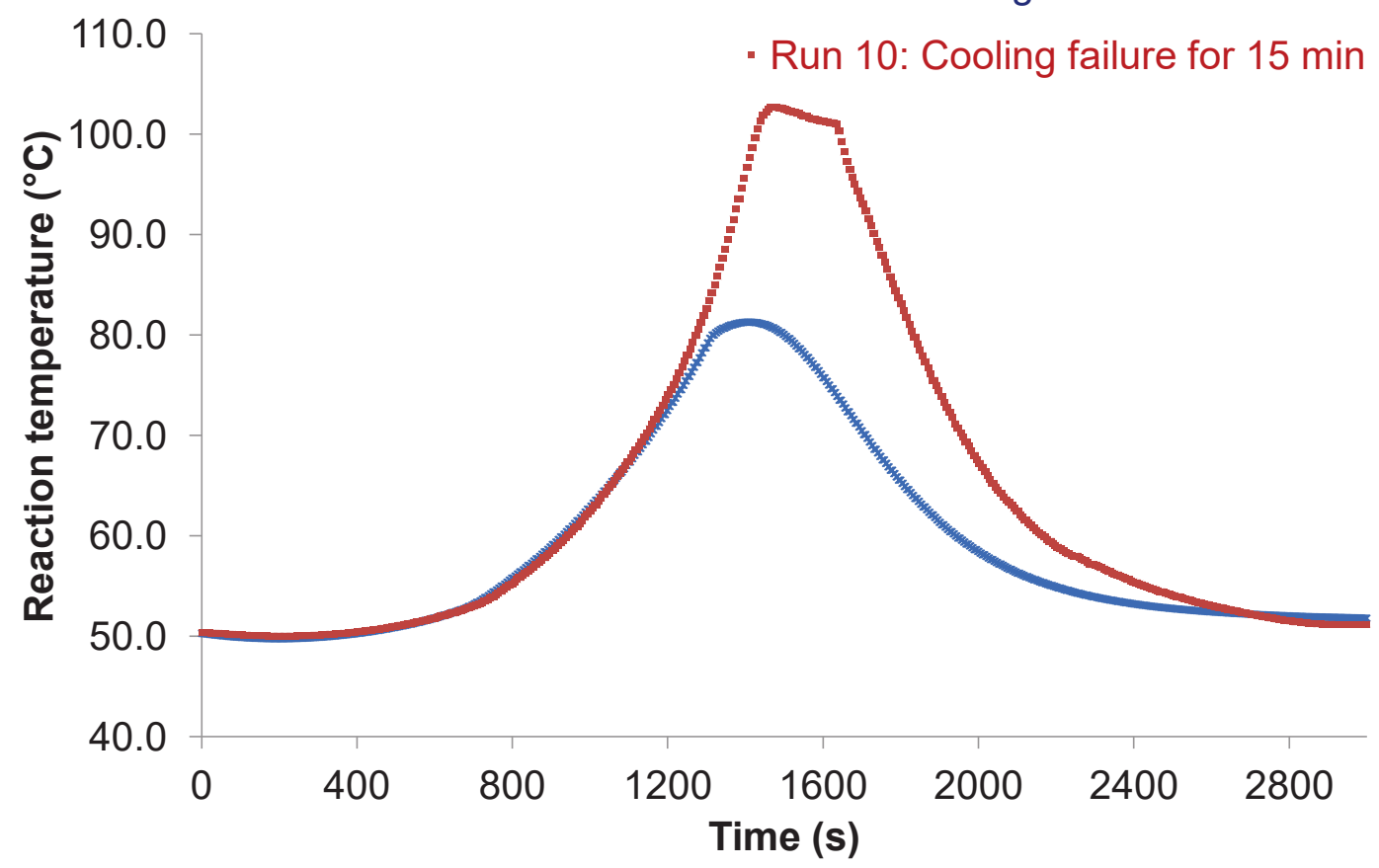

Fig. 12 - Evolution of reaction temperature for Runs $9 \& 10$. 
Fig. 12 shows the reaction temperature evolution for a cooling failure of 10 and 15 minutes. In case of 10 minutes (Run 9) of cooling failure, the maximum reaction temperature does not reach the boiling point, whereas at 15 minutes, the cooling system cannot compensate the heat-flow rate from the chemical reactions. 


\section{Conclusions}

Controlled cooling and stirring failure accidents were performed in a semi-batch reactor under isoperibolic mode at lab-scale. A liquid-liquid system composed of multiple exothermic reactions was used, i.e., oleic acid epoxidation by peroxyformic acid.

Safety criteria from DSC and ARC experiments were measured. It was found that $\mathrm{T}_{\mathrm{D} 24}$ was lower than the initial process temperature making the process in closed batch unreasonable. Furthermore, from ARC measurements, we have found that pressure increase was due to secondary reactions. Cooling failure accidents were performed in a semi-batch calorimeter equipped with a reflux condenser to determine the time to maximum temperature $t_{\max }$ and the maximum temperature $\mathrm{T}_{\mathrm{Rmax}}$.

Simulations revealed that the heat-flow rate of reactions from the organic phase was found higher than the heat-flow rate of reactions from the aqueous phase. The effect of stirring speed on the reaction temperature was investigated. By stopping the mechanical agitation, the peroxyformic acid mass transfer and epoxidation was retarded but also the heat transfer from reaction mixture to heat carrier. The decrease of the heat-flow rate of the reactions from the organic phase and the decrease of heat transfer from the reaction mixture to the heat carrier lead to a thermal runaway. Consequently, for this particular system with an oxidizing agent transfer, in case of cooling failure, the rotation should not be stopped. 
One should keep in mind that the adiabatic temperature rise and TMR at industrial-scale system can be higher and shorter because thermal inertia factor is closer to one. Thus, in case of cooling and/or stirring failure, the industrial system can reach real adiabatic conditions. To prevent such thermal risk, the addition of one reactant should be done slowly with an immediate system of feed-shutdown in case of cooling or stirring failure. 


\section{Notation}

A

$\overline{\mathrm{C}_{\mathrm{P}}}$

$\hat{\mathrm{C}}_{\mathrm{P}}$

$D_{e}$

$d_{s}$

$d_{w}$

$\mathrm{h}_{\mathrm{j}}$

$h_{R}$

$\Delta \mathrm{H}_{\mathrm{R}}$

k

$m_{R}$

$\mathrm{N}$

$\mathrm{Pi}$

$q_{F A}$

$q_{\text {acc }}$

$q_{\text {dosing }}$

qloss

qexchange to heat carrier

$q_{\text {reactions }}$ or $q_{r x}$

$r_{i}$

$\mathrm{T}_{\mathrm{R}}$ heat transfer area $\left[\mathrm{m}^{2}\right]$

constant-pressure heat capacity per mol $\left[\mathrm{J} \cdot \mathrm{mol}^{-1} \cdot \mathrm{K}^{-1}\right]$

constant-pressure heat capacity per mass $\left[\mathrm{J} \cdot \mathrm{g}^{-1} \cdot \mathrm{K}^{-1}\right]$

internal diameter of the reactor [cm]

stirrer diameter [cm]

thickness of the glass wall [cm]

conductivity of the stagnant film from jacket side $\left[\mathrm{W} \cdot \mathrm{m}^{-2} \cdot \mathrm{K}^{-1}\right]$

conductivity of the stagnant film from reaction side $\left[\mathrm{W} \cdot \mathrm{m}^{-2} \cdot \mathrm{K}^{-1}\right]$

Reaction enthalpy [J.mol $\left.{ }^{-1}\right]$

rate constant

mass $[\mathrm{kg}]$

rotation speed of the stirrer [rps]

partial pressure of i [MPa]

mass flow rate of formic acid $\left[\mathrm{g} \cdot \mathrm{min}^{-1}\right]$

accumulating heat-flow rate $\left[\mathrm{J} . \mathrm{s}^{-1}\right]$

sensible heat-flow rate $\left[\mathrm{J} . \mathrm{S}^{-1}\right]$

heat losses $\left[\mathrm{J}^{\mathrm{S}} \mathrm{S}^{-1}\right]$

heat-flow rate exchanged between heat carrier and reaction mixture [ ${\left.\mathrm{J} . \mathrm{S}^{-1}\right]}^{-1}$ reactions heat-flow rate $\left[\mathrm{J} . \mathrm{S}^{-1}\right]$

reaction rate $\left[\mathrm{mol} . \mathrm{L}^{-1} \cdot \mathrm{s}^{-1}\right]$

reaction temperature $[\mathrm{K}]$ 
$T_{j}$

U

V

$\mathrm{w}_{\mathrm{i}}$ jacket temperature $[\mathrm{K}]$

overall heat transfer coefficient $\left[\mathrm{W} \cdot \mathrm{m}^{-2} \cdot \mathrm{K}^{-1}\right]$

volume [L]

weight percent

Greek letters 
$\alpha$

$\beta$

$\lambda_{w}$

$\lambda_{R}$

$v_{i j}$

$\rho$

$\omega$

$\tau$

$\tau_{a q}$

$v_{i j}$

$\Delta T_{a d}$

$\varphi$

$1 / \varphi_{R}$ $\tau_{\text {aq }} / \tau$

proportionality factor $\left[\mathrm{J} \cdot \mathrm{MPa}^{-1} \cdot \mathrm{s}^{-1}\right]$

heat conductivity of the glass wall $\left[\mathrm{W} \cdot \mathrm{m}^{-1} \cdot \mathrm{K}^{-1}\right]$

reaction mixture thermal conductivity $\left[\mathrm{W} \cdot \mathrm{m}^{-1} \cdot \mathrm{K}^{-1}\right]$

stoichiometric coefficient

mass density $\left[\mathrm{kg} \cdot \mathrm{L}^{-1}\right]$

objective function

residence time $[\mathrm{s}]$

residence time in aqueous phase [s]

stoichiometric coefficient

adiabatic temperature rise

thermal inertia

$\frac{1}{h_{j}}+\frac{d_{w}}{\lambda_{w}}$ 
Subscripts and superscripts

$\begin{array}{ll}\text { acc } & \text { accumulation } \\ \text { add } & \text { addition } \\ \text { aq } & \text { aqueous phase } \\ \text { decomp } & \text { decomposition } \\ \text { Ep } & \text { epoxidized compounds } \\ \text { feed } & \text { feed } \\ \text { j } & \text { jacket } \\ \text { org } & \text { organic phase } \\ \text { perh } & \text { perhydrolysis } \\ \text { R } & \text { reaction mixture } \\ \text { ROFA } & \text { ring-opening by formic acid } \\ \text { ROPFA } & \text { ring-opening by peroxyformic acid } \\ \text { ROW } & \text { ring-opening by water } \\ \text { temp } & \text { temperature } \\ \text { O } & \text { Initial }\end{array}$

Abbreviations 
ARC

ARSST

DSC

EpOA

FA

HP

MTSR

MTT

OA

PFA

$\mathrm{TMR}_{\mathrm{ad}}$

$\mathrm{T}_{\mathrm{D} 24}$

$\mathrm{T}_{\mathrm{D} 8}$

$T_{P}$

W accelerating rate calorimeter

advanced reactive system screening tool

differential scanning calorimeter

epoxidized oleic acid

formic acid

hydrogen peroxide

maximum temperature for synthesis reactions

maximum temperature for technical reasons

oleic acid

peroxyformic acid

time-to-maximum-rate under adiabatic conditions

process temperature when $\mathrm{TMR}_{\mathrm{ad}}$ is 24 hours

process temperature when $\mathrm{TMR}_{\mathrm{ad}}$ is 8 hours

process temperature

water 
Financial support from Academy of Finland is gratefully acknowledged. The authors thank Energy Efficiency and Environment: Cross Channel Cluster (E3C3). The E3C3 project ( $\left.n^{\circ} 4274\right)$ was selected by the European INTERREG IV A France (Channel) - England Cross-border Cooperation Programme, cofinanced by ERDF. The authors thank particularly Jean-Pierre Hébert for his technical assistance. 


\section{References}

Anastas, P.T., Warner, J.C., 2000. Green Chemistry: Theory and Practice. Oxford University Press, Oxford.

Campanella, A., Rustoy, E., Baldessari, A., Baltanás, M.A., 2010. Lubricants from chemically modified vegetable oils. Bioresource Technology 101, 245-254.

Copelli, S., Derudi, M., Cattaneo, C.S., Nano, G., Raboni, M., Torretta, V., Rota, R., 2014. Synthesis of 4-Chloro-3-nitrobenzotrifluoride: Industrial thermal runaway simulation due to cooling system failure. Process Safety and Environmental Protection 92, 659-668.

Boucot, P., Bournay, L., Bronner, C., Chodroge, J.-A., Forestiere, A., Hillion, G., 2003. Process for the production of alkyl esters from vegetable or animal oil and an aliphatic monohydric alcohol. EP1352893 A1

de Quadros Jr., J.V., Giudici, R., 2016. Epoxidation of soybean oil at maximum heat removal and single addition of all reactants. Chemical Engineering and Processing: Process Intensification 100, 87-93.

Leveneur, S., Thönes, M., Hébert, J.-P., Taouk, B., Salmi, T., 2012. From Kinetic Study to Thermal Safety Assessment: Application to Peroxyformic Acid Synthesis. Ind. Eng. Chem. Res. 51, 13999-14007.

Leveneur, S., Zheng, J., Taouk, B., Burel, F., Wärnå, J., Salmi, T., 2014a. Interaction of thermal and kinetic parameters for a liquid-liquid reaction system: Application to vegetable oils epoxidation by peroxycarboxylic acid. Journal of the Taiwan Institute of Chemical Engineers 45, 1449-1458. 
Leveneur, S., Delannoy, F., Levesqueau, Y., Hébert, J.-P., Estel, L., Taouk, B., Salmi, T., 2014b. The limit of DSC as a Preliminary Tool to Determine the Safety Parameters?, Chemical Engineering Transactions. 36, 139-144.

Leveneur, S., Estel, L., Crua, C., 2015. Thermal risk assessment of vegetable oil epoxidation. Journal of Thermal Analysis and Calorimery.

Maestri, F., Rota, R., 2006. Temperature diagrams for preventing decomposition or side reactions in liquid-liquid semibatch reactors. Chemical Engineering Science 61, 3068-3078.

Monono, E.M., Haagenson, D.M., Wiesenborn, D.P., 2015. Characterizing the epoxidation process conditions of canola oil for reactor scale-up. Industrial Crops and Products 67, 364-372.

Ni, L., Jiang, J., Mebarki, A., Zhang, M., Dou, Z., Pensee, V., 2016. Thermal risk in batch reactors: Case of peracetic acid synthesis. Journal of Loss Prevention in the Process Industries 39, 85-92.

Nohra, B., Candy, L., Blanco, J.-F., Guerin, C., Raoul, Y., Mouloungui, Z., 2013.

From Petrochemical Polyurethanes to Biobased Polyhydroxyurethanes. Macromolecules 46(10), 3771-3792.

Rosillo-Calle, F., Pelkmans, L., Walter, A., 2009. A global overview of vegetable oils, with reference to biodiesel. Report of IEA Bioenergy

Salzano E., Garcia Agreda A., Russo V., Di Serio M., Santacesaria E., 2012. Safety Criteria for the Epoxydation of Soybean Oil in Fed-Batch Reactor. Chemical Engineering Transactions 26, 39-44. 
Santacesaria, E., Tesser, R., Di Serio, M., Turco, R., Russo, V., Verde, D., 2011. A biphasic model describing soybean oil epoxidation with $\mathrm{H}_{2} \mathrm{O}_{2}$ in a fed-batch reactor. Chemical Engineering Journal 173, 198-209.

Sempere, J., Nomen, R., Serra, R., Cardillo, P., 1997. Thermal hazard assessment using closed-cell adiabatic calorimetry. Journal of Loss Prevention in the Process Industries 10, 55-62.

Sengupta, D., Pike, R.W., 2013. Chemicals from biomass, integrating bioprocesses into chemical production complexes for sustainable development. CRC Press.

Sinadinović-Fišer, S., Janković, M., Borota, O., 2012. Epoxidation of castor oil with peracetic acid formed in situ in the presence of an ion exchange resin. Chemical Engineering and Processing: Process Intensification 62, 106-113.

Steensma, M., Westerterp, K.R., 1991. Thermally safe operation of a semibatch reactor for liquid-liquid reactions-fast reactions. Chem. Eng. Technol. 14, 367375.

Steensma, M., Westerterp, K.R., 1990. Thermally safe operation of a semibatch reactor for liquid-liquid reactions. Slow reactions. Ind. Eng. Chem. Res. 29, $1259-1270$.

Steensma, M., Westerterp, K.R., 1988. Thermally safe operation of a cooled semi-batch reactor. Slow liquid-liquid reactions. Chemical Engineering Science $43,2125-2132$.

Stoessel, F., 2008. Front Matter, in: Thermal Safety of Chemical Processes. Wiley-VCH Verlag GmbH \& Co. KGaA, pp. I-XIX. 
Van Woezik, B.A.A., Westerterp, K.R., 2002. Runaway behavior and thermally safe operation of multiple liquid-liquid reactions in the semi-batch reactor: The nitric acid oxidation of 2-octanol. Chemical Engineering and Processing: Process Intensification 41, 59-77.

Zheng, J.L., Wärnå, J., Salmi, T., Burel, F., Taouk, B., Leveneur, S., 2016. Kinetic modeling strategy for an exothermic multiphase reactor system: Application to vegetable oils epoxidation using Prileschajew method. AIChE J. $62,726-741$. 